Discussion Paper No. 11-075

\title{
Capital Structure Choice
} and Company Taxation:

A Meta-Study

Lars P. Feld, Jost H. Heckemeyer, and Michael Overesch

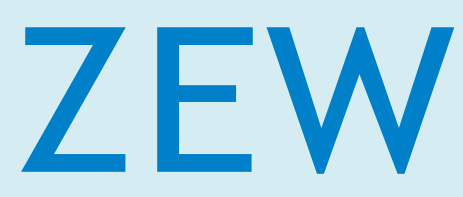

Zentrum für Europäische Wirtschaftsforschung $\mathrm{GmbH}$ Centre for European Economic Research 
Discussion Paper No. 11-075

\title{
Capital Structure Choice and Company Taxation: A Meta-Study
}

\author{
Lars P. Feld, Jost H. Heckemeyer, \\ and Michael Overesch
}

Download this ZEW Discussion Paper from our ftp server:

http://ftp.zew.de/pub/zew-docs/dp/dp11075.pdf

Die Discussion Papers dienen einer möglichst schnellen Verbreitung von neueren Forschungsarbeiten des ZEW. Die Beiträge liegen in alleiniger Verantwortung der Autoren und stellen nicht notwendigerweise die Meinung des ZEW dar.

Discussion Papers are intended to make results of ZEW research promptly available to other economists in order to encourage discussion and suggestions for revisions. The authors are solely responsible for the contents which do not necessarily represent the opinion of the ZEW. 


\section{Zusammenfassung}

Die Finanzierungstheorie hält bedeutende Argumente dafür bereit, dass der Verschuldungsgrad von Unternehmen von steuerlichen Faktoren beeinflusst wird. Die empirische Forschung hatte indes lange Jahre erhebliche Probleme, einen Zusammenhang zwischen der Kapitalstruktur von Unternehmen und ihrer Steuerbelastung zweifelsfrei nachzuweisen. Auch heute noch finden sich in der mittlerweile umfassenden Literatur zum Thema durchaus gemischte Ergebnisse. Überraschenderweise hat bisher jedoch keine Studie versucht, diejenigen Faktoren, die für die unterschiedlichen Ergebnisse verantwortlich sind, quantitativ zu untersuchen.

Die vorliegende Studie füllt diese Lücke. Sie präsentiert eine umfassende quantitative Auswertung der gesamten internationalen Literatur zum Zusammenhang zwischen Verschuldungsgrad und Steuersatz. Auf der Grundlage von über 1.000 Schätzergebnissen, die aus 46 Studien der Literatur entnommen wurden, zeigt sich, dass in der Tat ein positiver Einfluss des Steuersatzes auf die Verschuldung der Unternehmen besteht und dass dieser Zusammenhang auch ökonomisch relevant ist. Vor allem das in einer Studie gewählte Maß zur Approximation des marginalen steuerlichen Anreizes ist entscheidend für die Höhe des ausgewiesenen Effekts. Es kommt aber auch auf weitere Eigenschaften der Studien an. Zu nennen sind hier vor allem die untersuchte Fremdkapitalart und die ökonometrische Spezifikation der Analyse. Nachdem die Einflüsse etwaiger Fehlspezifkationen herausgrechnet wurden, ergibt sich aus der bisherigen empirischen Evidenz, dass der Verschuldungsgrad eines Unternehmens um 0,3 Prozentpunkte ansteigt, wenn sich sein Steuersatz um einen Prozentpunkt erhöht. 


\section{Non-Technical Summary}

Theoretical arguments for the tax sensitivity of capital structures are convincing. Empirical findings instead have for years been rather weak. Even today, despite a surge of studies providing point estimates for the tax effect on corporate capital structure, the empirical evidence remains ambiguous. Surprisingly, however, no study has ever quantitatively examined the factors which determine the variation in empirical evidence.

The contribution of this paper is to fill this gap. It provides a comprehensive quantitative review of the empirical literature on the impact of taxation on corporate debt financing. Synthesizing the evidence from over 1,000 primary estimates extracted out of 46 studies, we find that this impact is indeed quite substantial. Our results suggest that, in particular, the tax rate proxy used for identification determines the outcome of primary analyses. More refined measures like the simulated marginal tax rate suggested by Graham $(1996,1999)$ avoid a significant downward bias in estimates for the debt response to tax. Moreover, we find that debt characteristics, the econometric specification, the set of control-variables, and publication selection in primary studies exert significant influence on estimated tax effects. Accounting for all potential misspecification biases by means of meta-regression analyses, we predict a marginal tax effect on the debt ratio of 0.3 . 


\title{
Capital Structure Choice and Company Taxation:
}

\author{
A Meta-Study
}

\author{
Lars P. Feld ${ }^{\mathrm{a}}$, Jost H. Heckemeyer ${ }^{\mathrm{b}}$, Michael Overesch ${ }^{\mathrm{c}}$
}

March 2011

\begin{abstract}
This paper provides a quantitative review of the empirical literature on the tax impact on corporate debt financing. Synthesizing the evidence from 46 previous studies, we find that this impact is substantial. In particular, the tax rate proxy determines the outcome of primary analyses. Measures like the simulated marginal tax rate (Graham (1996a)) avoid a downward bias in estimates for the debt response to tax. Moreover, debt characteristics, econometric specifications, and the set of control-variables affect tax effects. Accounting for misspecification biases by means of meta-regressions, we predict a marginal tax effect on the debt ratio of 0.3 .
\end{abstract}

Keywords: Capital Structure, Corporate Income Tax, Meta-Analysis.

JEL Code: G30, H32, F23

We would like to thank Michael P. Devereux, Tom Stanley and participants of the Congress of the International Institute of Public Finance in Cape Town, the Workshop on Meta-Analysis in Economic Research in Corvallis (Oregon) and the Annual Meetings of the German Economic Association (VfS) in Kiel and the VHB in Bremen for valuable comments. The usual disclaimer applies.

${ }^{a}$ University of Freiburg, Walter Eucken Institute, Goethestrasse 10, 79100 Freiburg, Germany, lars.feld@waltereucken-institut.de.

b Centre for European Economic Research (ZEW), L7,1, 68161 Mannheim, Germany, heckemeyer@zew.de.

c University of Frankfurt, Business School, 60323 Frankfurt, Germany, overesch@wiwi.uni-frankfurt.de. 


\section{Introduction}

Theoretical arguments for the tax sensitivity of capital structures are convincing. Empirical findings instead have for years been rather weak. Only 12 years ago, Parrino and Weisbach (1999: 39) concluded:

"Despite over 40 years of research, we still know surprisingly little about the determinants of capital structure. There is general agreement that debt has a tax advantage over equity, but disagreement over the magnitude of this tax advantage and the relative importance of the costs of debt that offset this tax advantage at the margin."

Even today, despite a surge of studies providing point estimates for the tax effect on corporate capital structure, the empirical evidence remains ambiguous. Surprisingly, however, no study has ever quantitatively examined the factors which determine the variation in empirical evidence. The contribution of this paper is to fill this gap. We do not put forward another direct estimate of the tax effect on corporate capital structure. We instead present a meta-analysis of the empirical literature, using econometric methods to synthesize the previously obtained evidence. By taking recourse to meta-regression analyses, we can systematically relate variation in sign and size of reported tax effects on capital structure to underlying primary study and data characteristics (Stanley (2001)). Our study thus complements excellent qualitative surveys of the tax response of capital structure choices (e.g., Graham (2003)).

The fundamental argument for a tax effect on corporate financial policy relies on an important benefit associated with debt financing, which is the interest tax shield. According to most tax systems, interest expenses are deductible from corporate taxable income while equity payouts are 
not. The value of the implied tax shield from interest deductions clearly grows with the marginal tax rate (Modigliani and Miller (1963)). Several theoretical models explain capital structure choices of firms as result of a trade-off between the benefit and the cost of debt financing. While cost is, for example, related to financial distress (Kraus and Litzenberger (1973)) or agency conflicts between equity and debt claimants (Jensen and Meckling (1976); Myers (1977)), the tax shield significantly contributes to the benefit of debt. ${ }^{1}$ The general tax advantage of debt is also acknowledged if capital structure choices follow other concepts (Gordon (2010)), like pecking order (Myers and Majluf (1984)) or market timing theory (Baker and Wurgler (2002)).

This study provides a comprehensive quantitative assessment of the existing empirical evidence on the marginal debt response to tax. We thus aim to shed light on the underlying causes of the disagreements highlighted by Parrino and Weisbach (1999). For this purpose, we extract 1,143 point estimates of the marginal tax effect on the debt ratio out of 46 studies. While a lot of primary studies indeed report positive tax effects on debt financing, surprisingly, a number of studies also find robust evidence suggesting a negative effect of taxes on leverage (e.g., Booth et al. (2001); Huang and Ritter (2009)). Synthesizing the evidence by means of meta-regression analyses, we conclude that the tax impact on debt is indeed substantial. Our results suggest that, in particular, the tax rate proxy used for identification determines the outcome of primary analyses. More refined measures like the simulated marginal tax rate suggested by Graham (1996a, 1999) avoid a significant downward bias in estimates for the debt response to tax.

\footnotetext{
${ }^{1}$ Non-tax explanations for a benefit of debt are discussed in the literature, as well. Jensen (1986) and Stulz (1990), e.g., argue that debt can help to reduce agency problems between managers and stockholders.
} 
Moreover, we find that debt characteristics, the econometric specification, the set of controlvariables, and publication selection in primary studies exert significant influence on estimated tax effects. Accounting for all potential misspecification biases, we predict a positive marginal tax effect on the debt ratio of 0.3 .

Some recent studies focus on capital structures and related tax planning activities of multinational firms. We extensively deal with this literature, as well. Generally, our results suggest that the tax effects on debt are higher in the case of multinational firms. We conclude that tax incentives associated with multinational activity should be modeled very carefully, with an emphasis on the additional incentives arising from cross-border profit shifting opportunities. Furthermore, evaluating all relevant studies in the literature, we can securely conclude that intracompany debt is the most flexible device to respond to tax incentives.

The remainder of the paper is organized as follows. In Section II, we survey the empirical evidence on the impact of taxes on capital structure choices. A description of the meta-regression investigation approach is provided in Section III. Thereafter, in Section IV our meta-sample is presented and the meta-variables are described in Section V. The results of the meta-regressions are presented in Section VI. Finally, Section VII concludes.

\section{Survey of the Empirical Evidence}

Theoretical arguments for the tax sensitivity of companies' capital structures are strong. By contrast, empirical support has for long time been rather weak. Faced with the discrepancy 
between theory and observed evidence (Myers (1984); Parrino and Weisbach (1999)), empirical researchers accepted the challenge. During the last two decades, numerous studies have indeed documented a significant tax effect on the debt policy of firms. A first strand of literature avoids the use of direct marginal tax rate (MTR) proxies altogether (see MacKie-Mason (1990); Dhaliwal et al. (1992); Trezevant (1992); Downs (1993); Barklay and Smith (1995); Graham and Tucker (2006)). Instead, these studies exploit the DeAngelo and Masulis (1980) finding of a significant correlation between non-debt tax shields and the unobserved true MTR. While these studies indirectly confirm a significant tax impact on debt financing by reporting strong effects of non-debt tax shields, another strand of literature has directly estimated quantitative effects of taxes. Since the aim of our study is a quantitative assessment of the existing empirical evidence, we review those studies which provide point estimates for the marginal tax effect on capital structure choices. $^{2}$

The identification of the quantitative tax effect on corporate debt levels hinges upon an adequate approximation of the unobserved marginal tax incentive to finance with debt. Importantly, the tax benefit of debt is a function of not only statutory tax rates but various dynamic features of the tax code. It results from firm-specific characteristics which interact with various details of the tax code like non-linear tax scales, investment tax credits, or loss carryback and carryforward rules.

\footnotetext{
${ }^{2}$ Some studies do not examine tax effects on debt, but focus on related variables such as leasing or interest expenses (see e.g. Sharpe and Nguyen (1995); Ayers et al. (2001)). As we are interested in the direct quantitative impact of a change in the MTR on capital structure choices, we exclude these papers from the following survey. For the same reason, we do not consider studies that refer to incremental debt (see e.g. Graham (1996a); Alworth and Arachi (2001); Amromin and Liang (2003)) or bond offerings (see e.g. Newberry and Dhaliwal (2001)). For a thorough survey see Graham (2003).
} 
Still, empirical researchers have been quite innovative in capturing the marginal tax advantage of debt. A milestone in this respect was set by Shevlin (1990) and Graham (1996a, 1999). They simulate firm-specific marginal tax rates over a forecasted stream of taxable income, integrating the most important dynamic features of the tax code. ${ }^{3}$

Graham et al. (1998) and Graham (1999) regress debt-to-firm values of U.S. companies on these simulated tax rates. In addition, Graham (1999) extensively examines the role of personal taxes. Under most tax regimes, personal taxes inflict a tax penalty on interest income relative to returns on equity. Graham shows that the net tax benefit of debt significantly influences corporate debt financing. The same holds true for the gross tax advantage at the corporate level, and in addition, for the personal tax penalty itself. In an application to debt-to-value ratios of a cross-section of large listed U.S. firms, Graham et al. (2004) extend the simulation of MTRs and include employee stock option deductions.

Graham (1996b) and Graham and Mills (2008) document that the simulated marginal tax rate indeed is the best available proxy for the unobserved true marginal tax rate. Still, due to the complex nature of the simulation procedure, empirical analyses are often based on proxies which are easier to calculate. Many studies consider information on firm-level tax payments and compute an average tax rate as taxes paid divided by the pre-tax income of the firm. Booth et al. (2001) resort to average tax rates when analyzing the determinants of capital structures in various

\footnotetext{
${ }^{3}$ Recently, Graham and Kim (2009) and Blouin et al. (2010) suggest new procedures to simulate marginal tax rate measures. Yet, we know of no study that uses these new tax measures in a capital structure regression. Therefore, these measures cannot be considered by our meta-study.
} 
developing countries. Like several papers that consider average tax rates, however, they report only insignificant or even negative tax effects on the use of debt financing.

A straightforward but much simpler approximation of the tax benefit of debt is the statutory corporate income tax rate. The studies by Gordon and Lee $(2001,2007)$ take advantage of the progressive corporate income tax scale in the U.S. and exploit variation in relative statutory tax rates.

In particular, average or statutory tax rates suggest themselves as proxies for the tax incentive in studies which focus on international accounting and tax data. In these cases, the identifying variation emerges from international differences in tax legislation. Rajan and Zingales (1995) were the first to look at systematic determinants of capital structure choices across countries. Based on consolidated financial statements, their analysis remains rather descriptive. Inspired by this first approach, numerous studies use cross-country data to disentangle the determinants of corporate financial policies. Some of these papers exploit cross-country samples but keep a focus on domestic firms (Overesch and Voeller (2010)). However, new important research questions arise if multinational firms are considered. As these have subsidiaries in more than just one country, additional tax incentives affect corporate debt policy. Precisely, subsidiaries of multinational firms do not exclusively rely on debt from external sources. They can also borrow internally from their parent company or from other affiliated companies. This opens up possibilities to reallocate debt within the multinational and to exploit international tax rate differentials in a way that the overall company tax burden is reduced. Papers dealing with tax 
incentives at work within the multinational group necessarily deviate from Rajan and Zingales (1995) in that they use non-consolidated financial statements of subsidiaries. Only on the basis of this unconsolidated data, host-country taxes can be attributed to internal leverage.

Altshuler and Grubert (2003) and Desai et al. (2004) were the first to examine balance sheet data of foreign subsidiaries of multinational corporations. More recently, improved data availability favored the assessment of tax effects on capital structures of European multinationals (Huizinga et al. (2008); Buettner et al. (2009); Mintz and Weichenrieder (2010)). Altshuler et al. (2003) and Mintz and Weichenrieder (2010) find significant tax effects only on internal debt ratios. By contrast, Desai et al. (2004) and Buettner et al. (2009) report significant effects for both external and intra-company debt. While the marginal tax effect on companies' debt ratio is higher for third-party debt, the tax elasticity, however, turns out to be more pronounced for intra-company debt financing.

By means of an internal reallocation of debt, multinationals can shift profits from high-tax jurisdictions to low-tax jurisdictions. ${ }^{4}$ Huizinga et al. (2008) empirically split the total tax effect on the debt policy of multinational firms into a purely domestic effect and an international profit shifting incentive. The latter is identified by the tax rate differential between the host-country tax rate and a weighted average of the statutory tax rates available within the multinational firm. Their results document that ignoring the shifting motive significantly underestimates the overall

\footnotetext{
${ }^{4}$ Since debt financing is a potential channel through which profits are shifted from high- to low-tax countries, there are attempts to restrict the use of inter-company loans by introducing what is called thin-capitalization or earning stripping rules. The effects of thin-capitalization rules are considered by some recent studies like Buettner et al. (2008) and Overesch and Wamser (2010).
} 
tax response. Moreover, some empirical studies focus on the tax asymmetries between subsidiary and parent company. Mills and Newberry (2004) find a negative impact of the tax level of parent companies on debt financing of foreign controlled subsidiaries in the U.S.

This brief survey shows that numerous studies provide point estimates for the marginal tax effect on capital structure choices; however, the reported evidence as well as the empirical approaches vary significantly. Studies particularly differ in the employed proxy for the marginal tax rate, their focus on tax incentives (e.g., corporate taxes, personal taxes, international taxation), the type of firms (e.g., domestic firms, multinational firms) and in the data sources. In the following sections, we analyze whether and to what extent these different study characteristics systematically explain the heterogeneous estimates for the tax effect on the corporate debt ratio.

\section{The Concept of Meta-Regression}

Meta-regression analysis is a form of quantitative literature survey. It relies on econometric methods to systematically disentangle the quantitative impact of explicit or implicit choices of study design on obtained empirical evidence. Exploiting the virtues of statistical analyses metaregression analysis reasonably complements high-quality narrative surveys (Stanley (2001)). Various applications of meta-analysis are put forward in several fields of economics. ${ }^{5}$ In a meta-

\footnotetext{
${ }^{5}$ Meta-analysis is applied, for example, in the field of international economics by Goerg and Strobl (2001) on productivity spillovers associated with multinational firm activity, by De Mooij and Ederveen (2003) or Feld and Heckemeyer (2011) on taxation and foreign direct investment; in the field of labor economics by Card and Krueger (1995) on minimum wage effects, by Stanley and Jarrell (1998) on gender wage discrimination and by Card et al. (2010) on labor market policy evaluations; or in the field of environmental economics by Smith and Huang (1995) on property value models.
} 
regression, an effect size index, often a regression parameter, extracted from primary analyses is taken as dependent variable and modelled as a function of (mostly) dummy variable predictors which represent differences in method, design and data used by the primary estimation. Metaregression analysis thus helps to systematically explain the considerable variation found in empirical research. Put differently, it helps to offer specific reasons, based on the primary analyses themselves, why the evidence on a certain question may appear contradictory or strongly varied (Stanley (2001)).

In our meta-regressions, we refer to the marginal tax effect on the corporate debt ratio estimated in primary studies as our dependent variable. This effect size index represents the percentagepoint change of the debt ratio in response to a one percentage-point change in the tax rate. It indicates the debt change in percent of total assets, triggered by a one percentage-point change in the tax rate. Generally, the literature provides point estimates of this marginal tax effect.

Equation (1) illustrates the marginal tax effect on the corporate debt ratio (me) more formally, where $d$ represents the debt ratio as defined by debt $D$ and total assets $A$ and $\tau$ is the tax rate:

$$
\text { me }=\frac{\partial \mathrm{d}}{\partial \tau}=\frac{\partial\left(\frac{D}{A}\right)}{\partial \tau}
$$

The meta-regression we estimate takes the linear form depicted in equation (2), where $y$ corresponds to the vector of estimated marginal tax effects drawn from primary analyses and $\boldsymbol{X}$ is a matrix of predominantly dummy variables that reflect various study or model characteristics. 


$$
\mathbf{y}=\mathbf{X} \boldsymbol{\beta}+\boldsymbol{\varepsilon}
$$

Since $\boldsymbol{y}$ includes estimated coefficients which are derived from models which in their great majority conform to the assumptions of the classical linear model, the meta-regression errors $\boldsymbol{\varepsilon}$ should be normally distributed. Equation (2) is, however, clearly heteroskedastic as the variance of the primary estimates is related to the characteristics of a study.

One approach in the literature to deal with the presence of heteroskedasticity is to use OLS with robust standard errors; but, in the clear presence of heteroskedasticity - as it is the case in metaregression analysis - least squares can be extremely inefficient (Greene (2003), p. 226). Fortunately, in the case of meta-regression, a measure of the heteroskedasticity is readily available: Coefficient standard errors are given in nearly all primary results tables. Thus, weighted least squares (WLS) with inverse squared primary standard errors as analytic weights is the obvious method of obtaining efficient meta-regression estimates (Stanley (2008); Greene (2003); Hedges and Olkin (1985)). Technically, efficiency is obtained by giving those reliable primary estimates of the marginal tax effect a greater influence, which are less affected by sampling error and thus show small variances.

\section{The Meta-Dataset}

For the purpose of this meta-study we thoroughly surveyed 46 primary studies in total. These were identified by comprehensively searching the EconLit database for empirical literature on the tax sensitivity of corporate capital structure choices. Precisely, we searched the database for 
the central keywords "Capital Structure" and "Tax". Furthermore, we conducted additional internet searches and scanned relevant journals as well as working paper series. ${ }^{6}$

We sample all tax effect estimates found in each relevant primary study. Such multiple sampling allows for more accurate estimates and inference due to a larger underlying sample as compared to single estimate sampling. Otherwise, selecting one single estimate from each study would require predefined and - most importantly - objective sampling rules, which can hardly be justified. Moreover, the additional heterogeneity obtained from considering all robustness checks reported in a study is welcome in statistical meta-analyses.

Our basic sample (Sample A) of primary study results contains all marginal tax effects on the debt ratio which mainly result from variation in the domestic tax rate. In some cases these effects might jointly reflect both domestic tax incentives and the international profit shifting incentive. In addition, in our Sample B we even more rigorously exclude all tax effects estimated on the bases of multinational company data. In return, we define a Sample C of tax effect estimates drawn from studies which focus exclusively on multinational subsidiaries. Here, we also add effect estimates which exclusively reflect profit shifting incentives.

After all, the three subsamples join to a full meta-dataset of 1,143 observations obtained from the 46 studies, each representing one estimated marginal tax effect on the corporate debt ratio. Table I provides some descriptive statistics at sample level. More detailed statistics for every

\footnotetext{
${ }^{6}$ We particularly searched through the Journal of Finance, Journal of Financial Economics, Review of Financial Studies, Journal of Public Economics, Journal of Financial and Quantitative Analysis, Journal of Corporate Finance, Financial Management, European Financial Management, National Tax Journal, International Tax and Public Finance, and the SSRN working paper database.
} 


\section{Table I}

\section{Descriptive Statistics}

Sample A denotes the basic sample containing all marginal tax effects on the debt ratio which mainly result from variation in the domestic tax rate. In some cases these effects might jointly reflect both domestic tax incentives and the international profit shifting incentive. Sample B excludes estimates based on pure multinational firm data. By contrast, Sample C contains only tax effect estimates drawn from studies which focus exclusively on multinational subsidiaries.

\begin{tabular}{|c|c|c|c|c|c|c|c|}
\hline \multirow{2}{*}{ Sample } & \multirow{2}{*}{$\begin{array}{l}\text { No. of } \\
\text { Studies }\end{array}$} & \multirow{2}{*}{$\begin{array}{l}\text { No. of } \\
\text { Effects }\end{array}$} & \multicolumn{5}{|c|}{ Marginal Tax Effects on Debt } \\
\hline & & & Mean & Median & Min & Max & Std. \\
\hline Basic Sample (A) & 43 & 1012 & 0.13 & 0.07 & -2.30 & 3.82 & 0.42 \\
\hline Excluding Pure Multinational Studies (B) & 29 & 660 & 0.11 & 0.03 & -2.30 & 3.82 & 0.48 \\
\hline Exclusive Multinational Studies (C) & 19 & 453 & 0.16 & 0.11 & -0.95 & 1.05 & 0.22 \\
\hline Overall Meta-Dataset & 46 & 1143 & 0.13 & 0.08 & -2.30 & 3.82 & 0.39 \\
\hline
\end{tabular}

single primary study can be found in Table VI in the Appendix. Most studies contribute either to the non-international sample (Sample B) or the international sample (Sample C); some studies contribute to both. In total, our basic sample includes primary estimates from 43 studies, while Sample B and Sample C respectively regroup evidence from 29 and 19 studies. $^{7}$

Table I shows that with a value of 0.16 the mean marginal tax effect is most pronounced in Sample C, which includes those studies with an exclusive focus on multinational firms. Instead, the mean marginal tax effect in Sample B, which in return excludes these studies, amounts to 0.11. Consistently, the Basic Sample A as well as the overall meta-dataset display means of 0.13. Median marginal effects are below the means in all meta-samples, hinting at sample distributions

\footnotetext{
${ }^{7}$ As explained in the text, the basic sample does not include estimates reflecting only international profit shifting incentives of multinational firms. Therefore, all estimates from Mills and Newberry (2004), Aggarwal and Kyaw (2008) as well as Overesch and Wamser (2010) are excluded from it.
} 
which are positively skewed. Notably, in Sample B 50\% of all primary estimates report marginal tax effects less than 0.03 . Still, the range of values is considerable. In particular, the relative dispersion of estimates turns out to be high. The relative standard deviation, calculated as the ratio of the absolute standard deviation to the mean, is above 3 and 4, respectively, in Samples A and B, and still exceeds a value of 1 in Sample C. Table VI in the Appendix corroborates this finding of high variation in marginal tax effects. Within a considerable number of studies, relative standard deviations are again above 1 . Obviously, the variation in our meta-samples has its origin not only in varied evidence between studies, but also within studies. We aim to systematically explain both between and within-study variance of reported marginal tax effects by meta-regressions.

\section{The Meta-Variables}

A central challenge in conducting a quantitative meta-study is to find an agreement over which study characteristics, i.e. meta-regression moderator variables, are the important ones to include in the analysis (Stanley (2001)). Regarding the literature on the tax sensitivity of capital structure, however, we are convinced that the essential study characteristics can be inferred from the narrative review of the empirical evidence in Section II. Furthermore, the primary studies themselves often raise and discuss pivotal issues in empirical research on corporate capital structure. Finally, we clearly benefit from insightful work put forward by, for example, Graham (2003), Frank and Goyal (2007) or Lemmon et al. (2008). 
After all, we presume six main groups of study characteristics to substantially drive the varied empirical results on the tax sensitivity of capital structures. We will therefore consider them as explanatory variables in our meta-regressions.

\section{A. Proxies for the Marginal Tax Incentive}

A central focus is, of course, on the tax measure employed for analysis. The literature survey in Section II highlighted that researchers have used different tax measures to capture the marginal tax advantage of debt. Therefore, we carefully classify proxies for the marginal tax incentive according to their degree of refinement and computational complexity.

An easily available proxy for the marginal tax incentive is the statutory corporate income tax rate. It might, however, only be a rough approximation. Unless the corporate tax scale is progressive, this measure does not capture any firm-specific information on the corporate tax status. If a firm finds itself near tax exhaustion due to low profitability, accrued non-debt tax shields or tax loss carry-forwards, its marginal tax incentive to finance with debt is going to fall short of what the statutory tax rate suggests. Identified effects of the statutory tax rate on debt might therefore underestimate the true relationship between the marginal tax rate and capital structure choices. Consequently, some empirical researchers refrain from using statutory tax rates in their capital structure regressions. Instead, they use more refined approaches to take into account information on the actual tax status of the firm.

The previous empirical literature employs mainly two methods to approximate the tax incentive of debt financing more carefully. The first group opts for an average tax rate computed as paid 
taxes divided by pre-tax income. The tax payments which figure in the numerator of the average tax rate implicitly capture the degree of tax exhaustion and its implications for the incentive to finance with debt.

Still, some caveats remain which keep the average tax rate from being a precise proxy for the effectively decisive economic marginal tax rate. ${ }^{8}$ First, in the terminology of Graham (2003), the average tax rate still is to be qualified as a rather static proxy. It clearly misses the fact that a firm's economic tax status considerably depends on its future profitability. Second, the average tax rate by definition reflects the tax burden on an average dollar of income. Additional interest deductions will, however, shield marginal income from taxation. Thus, the exact tax benefit of debt at the corporate decision margin is systematically missed.

As highlighted in the literature survey of Section II, Shevlin (1990) and Graham (1996a, 1999) therefore propose a different method and put forward a sophisticated stochastic simulation technique to compute firm-specific effective marginal tax rates. The simulation procedure according to Graham accounts for the most important dynamic features of the US tax code, i.e. net operating loss carry-forwards and carry-backs, investment tax credits and the alternative minimum tax. ${ }^{9}$

\footnotetext{
${ }^{8}$ The economic marginal tax rate according to Scholes and Wolfson (1992) is defined as the present value of current and future taxes owed on an extra dollar of income earned today.

${ }^{9}$ Simulated marginal tax rates are calculated for each firm and year separately by assuming that taxable income follows a random walk with drift over 18 years into the future. Then, the present value of the tax bill is calculated. Afterwards, it is recalculated after adding one dollar to taxable income in the current period. Results from 50 simulations (based on 50 separate forecasts of taxable income) are averaged to finally represent the firm-specific marginal tax rate.
} 
Another pivotal issue in the conception of a proxy for the marginal tax rate is that the corporate tax status is endogenous to debt levels (Graham (2003)). If a company issues debt, it reduces its taxable income through interest deductions. The amount of taxable income again has direct influence on the statutory tax rate in progressive tax systems, on average tax rates or on simulated tax rates. If no precautions are taken in the computation of the tax variable, the reported tax effects on debt policy might be negatively biased. This has been thoroughly examined by Graham et al. (1998) for the case of simulated tax rates. Their study shows that simulated proxies based on taxable income before financing expenses are immune to these endogeneity concerns. As regards average tax rates, however, only a few studies tend to neutralize the impact of financial decisions by referring to before financing profits (e.g. Lasfer (1995); Charalambakis et al. (2008)) or by considering the host country median of average tax rates (e.g. Desai et al. (2004)).

To contrast studies employing the statutory tax rate with more sophisticated approaches, we code two binary dummy variables ATR and SMTR, which mark tax effect estimates respectively gained from average tax rates and the Graham simulated marginal tax rate.

\section{B. Debt Characteristics}

Generally, primary studies focus on different measurements and types of debt. Since we only consider studies in our meta-sample which have estimated the impact of a change in the MTR on capital structure choices, the dependent variable of the primary studies is always a share of debt in total funds; yet, the measurement of the debt share varies. The considered primary studies use 
debt measured at book values or at market values. In order to test if the definition of the dependent variable affects the tax effect, we consider a dummy variable Debt Measured at Book Value in our meta-regressions which is one if debt is measured at book values and zero if measured at market values.

Moreover, primary estimations often distinguish between debt items of different maturity. It is an empirical question whether debt maturity exerts a significant impact on the tax sensitivity. On the one hand, a smaller tax response of long-term debt can be expected because it is difficult to adjust to yearly fluctuations in the marginal tax incentive. On the other hand, long-term debt is associated with higher amounts of interest deductions, as compared to short-term debt items containing, for example, trade payables that do not carry any interest deductions. As taxdeductible interest causes the tax advantage of debt over equity financing, long-term debt could be more tax responsive. In order to analyze whether reported tax effects systematically depend on debt maturity, we code a dummy variable Long-Term Debt, which has the value one if a tax effect refers exclusively to long-term debt and the value zero otherwise. ${ }^{10}$

\section{Econometric Specification of Primary Studies}

The empirical literature dealing with capital structure choices has traditionally tried to explain changes in the capital structure of a firm with contemporaneous changes of capital structure determinants; but an immediate adjustment of the capital structure is not in line with the

\footnotetext{
${ }^{10}$ We abstain from separately analyzing the tax response of short-term debt because in our meta-sample the number of primary estimates that refer to short-term debt is very low (1.5\%). By contrast, $16.3 \%$ of our primary estimates refer to long-term debt,
} 
existence of adjustment costs. Therefore, some recent studies have modeled dynamic aspects of capital structure adjustment. ${ }^{11}$ By considering the lagged value of the debt share, a partial adjustment process is identified. Notably, a dynamic specification carries an important implication for the coefficient estimated for the tax rate. The coefficient only reflects the shortterm adjustment toward a target debt ratio, while the long-term effect is calculated by taking into account the adjustment speed. In our meta-regression analysis, we therefore consider a dummy variable Dynamic Specification, which marks tax coefficients from dynamic specifications.

Lemmon et al. (2008) show that corporate capital structures are to an important extent determined by unobserved time-invariant firm-specific factors. Some empirical analyses of the tax effect on corporate capital structure control for such unobserved firm-specific heterogeneity, which indeed might be correlated with tax levels. This, however, comes at the cost that the variation of tax rates between firms is absorbed by the firm-fixed effects. Gordon and Lee (2001) point out that in numerous studies, e.g. Graham et al. (1998) and Graham (1999), the identification of tax effects is indeed predominantly based on cross-sectional variation of tax rate proxies between firms. On the one hand, controlling for unobserved firm-fixed effects might therefore reduce reported tax effects on corporate capital structure. On the other hand, it might correct for unknown omitted variable bias. To find out, we explicitly define a binary dummy variable Firm Fixed Effects Included which marks estimates resulting from analyses where unobserved firm-fixed effects are modeled.

\footnotetext{
11 Studies which estimate a dynamic model of the capital structure choice comprise Fama and French (2002), Flannery and Rangan (2006), Antoniou et al. (2008), Lemmon et al. (2008) and Huang and Ritter (2009).
} 
A firm's individual corporate tax status varies over time and so does the marginal tax incentive to finance with debt. Nevertheless, there can also be unobserved time trends affecting all firms equally. Reasons why the general attractiveness of debt financing might change over time are, for example, general business cycle effects, financial crises or changes in the institutional environment. Leaving such time trends unmodeled in panel data analyses could affect the identification of tax effects on debt policy. We therefore code a binary dummy variable Time Fixed Effects Included marking primary estimates free of any potential biases resulting from unmodeled time trends.

\section{Control Variables in Primary Studies}

The isolation of the tax effect in capital structure regressions requires control for other non-tax factors which determine corporate debt ratios and are possibly correlated with tax. Indeed, their omission could considerably affect reported results.

Frank and Goyal (2007) thoroughly identify a core set of six observable capital structure determinants. Their list of the most relevant explanatory variables includes controls for firm size, tangibility, profit, inflation, firm-specific growth options and industry median leverage. Whether the disregard of these core determinants indeed influences reported partial tax effects on the debt ratio is an empirical question. In order to answer it, we code six binary dummy variables, one for 
each of these determinants. If estimates are obtained from regressions including such a control variable, the respective dummy is one. Otherwise it has the value zero. ${ }^{12}$

\section{E. Data Sample Characteristics}

The 46 primary studies in our meta-sample are based on 20 different databases, which differ in terms of geographic coverage and types of firm represented. Some databases, e.g. Compustat, exclusively cover national firm data from only one country. Others, e.g. Compustat Global Vantage, cover cross-country firm data. As regards the types of firms represented in the data, some databases only contain information on publicly listed firms; others also include unlisted small and medium sized firms. Furthermore, some of the international databases focus exclusively on subsidiaries of multinational firms, e.g. Bureau of Economic Analysis data. Finally, the data coverage varies due to very different reporting obligations and data collection procedures across countries. In order to capture the heterogeneity of data used in primary studies, we will control for database fixed effects in our meta-regressions.

Furthermore, the data used in primary empirical studies is disclosed at very different dates. While, for example, Gordon and Lee (2001) have estimated tax coefficients based on data for a period from 1954 to 1995, other studies, e.g. Graham et al. (2004), provide evidence based on year 2000 data. The response to taxes might, however, vary over time because tax advisors are always searching for new tax planning strategies. Still, it is an empirical question whether the

\footnotetext{
${ }^{12}$ To mark estimates that rely on a specification taking into account a certain control variable, we group the control variables used in primary studies according to the classification chosen by Frank and Goyal (2007). For example, studies controlling for firm assets or firm sales are regrouped as controlling for firm size. Moreover, we consider industry fixed effects as a control for the typical leverage in that respective industry.
} 
refinement in tax optimal structures is not offset by the introduction of specific anti-avoidance rules. We therefore take into account a variable Average Sample Year which is the average disclosure year of the data used in the underlying estimation.

\section{F. Publication Selection}

It is an established conjecture that academic journals might have a tendency to publish papers with statistically significant results (De Long and Lang (1992)). Furthermore, the parties involved in the scientific publication process, i.e. both authors and journal reviewers, may prefer empirical results which comply with standard predictions concerning the direction of the assessed relationships. Consequently, research results which do not correspond to conventional economic theory in significance or sign might be doomed ("file-drawer problem”). If publication bias is indeed present, it can be statistically tested: If (and only if) there is publication selection in the literature, coefficient estimates and their associated standard errors will be correlated. The sign of the correlation will indicate the direction of the bias (Card and Krueger (1995); Egger et al. (1997); Stanley (2008)).

\section{Results}

\section{A. Main Results}

Our main results are displayed in Table II. The regressions are based on Sample A as described in Section IV. That is, we consider 1012 estimates of the marginal tax rate effect on debt shares 
provided by the literature. To analyze whether study characteristics systematically explain differences in reported tax coefficients, we regress marginal tax effects found in a primary empirical study on a set of meta-variables. These dummy variable regressions implicitly define an underlying benchmark study. The coefficients for each dummy variable reflect the average impact on reported tax effects if the study design deviates from the benchmark in that specific aspect. Respective benchmark characteristics are indicated in brackets for every control dummy in Table II.

Column (1) shows results of a baseline regression using ordinary least squares (OLS). Significant meta-regression coefficients suggest that econometric specification and control variables included in primary studies indeed affect the reported marginal tax effect. In column (2), we thoroughly analyze the impact of distinct tax rate measures which are frequently used in the literature. We include two dummy variables marking primary estimates referring either to simulated marginal tax rate or the average tax rate. Our benchmark is the statutory tax rate.

Specification (3) is augmented by the average sample year and the standard error of the tax coefficient in the primary study. Unlike the other variables used in our meta-regressions, the variables Average Sample Year and Primary Standard Error are no dummy variables. Consequently, no benchmark case can be denoted. In specification (4) we include database fixed effects. We presume that not only different econometric specifications and definitions of variables but also the type of data used in primary studies should affect the estimated tax response of capital structures. 
Table II

Meta-Regression of Reported Marginal Tax Effects on Debt Ratios, Base Sample

Regressions of the marginal tax effect found in primary studies on respective study characteristics. All study/model characteristics are coded as dummy variables (except Average Sample Year and Primary Standard Error). Thus, a base model represents the characteristics redundant to the variables explicitly included. The benchmark characteristics are indicated in parentheses for each study dimension. Estimated coefficients of the dummies indicate the effect on primary marginal effects of choosing a characteristic in lieu of the base specification. All regressions include a constant (not reported). The regressions are based on Sample A. Columns (1) - (4) of Table II show OLS-regression results; columns (5) and (6) are from WLS estimation. Heteroskedasticity robust standard errors in parentheses; $* * * / * * / *$ denotes significance at the $1 \% / 5 \% / 10 \%$ level.

\begin{tabular}{|c|c|c|c|c|c|c|}
\hline & \multicolumn{4}{|c|}{ OLS } & \multicolumn{2}{|c|}{ WLS } \\
\hline & (1) & (2) & (3) & (4) & (5) & (6) \\
\hline \multicolumn{7}{|l|}{ Proxies for the Marginal Tax Incentive } \\
\hline SMTR (Statutory Tax Rate) & & $\begin{array}{c}0.2856 * * * \\
(0.0743)\end{array}$ & $\begin{array}{c}0.2607 * * * \\
(0.0707)\end{array}$ & $\begin{array}{c}0.1138 \\
(0.0906)\end{array}$ & $\begin{array}{c}0.1069 * * * \\
(0.0176)\end{array}$ & $\begin{array}{c}0.0567 * * * \\
(0.0174)\end{array}$ \\
\hline ATR (Statutory Tax Rate) & & $\begin{array}{c}0.0440 \\
(0.0380)\end{array}$ & $\begin{array}{c}0.0488 \\
(0.0337)\end{array}$ & $\begin{array}{c}0.0320 \\
(0.0668)\end{array}$ & $\begin{array}{l}-0.0055 \\
(0.0083)\end{array}$ & $\begin{array}{c}-0.0310^{* * * *} \\
(0.0085)\end{array}$ \\
\hline \multicolumn{7}{|l|}{ Debt Characteristics } \\
\hline Long-Term Debt (Maturity not Specified or Short-Term) & $\begin{array}{c}0.1371^{* *} \\
(0.0662)\end{array}$ & $\begin{array}{c}0.2115 * * * \\
(0.0707)\end{array}$ & $\begin{array}{c}0.1576 * * * \\
(0.0581)\end{array}$ & $\begin{array}{l}-0.0024 \\
(0.0356)\end{array}$ & $\begin{array}{l}-0.0054 \\
(0.0086)\end{array}$ & $\begin{array}{l}0.0078^{*} \\
(0.0044)\end{array}$ \\
\hline Debt Measured at Book Values (Market Values) & $\begin{array}{l}-0.0449 \\
(0.0355)\end{array}$ & $\begin{array}{c}0.0511 \\
(0.0456)\end{array}$ & $\begin{array}{l}0.0746 * \\
(0.0450)\end{array}$ & $\begin{array}{c}0.0038 \\
(0.0276)\end{array}$ & $\begin{array}{c}-0.0064 * * \\
(0.0029)\end{array}$ & $\begin{array}{l}-0.0006 \\
(0.0013)\end{array}$ \\
\hline \multicolumn{7}{|l|}{ Econometric Specification of Primary Studies } \\
\hline Dynamic Specification (Static Specification) & $\begin{array}{c}-0.1558 * * * \\
(0.0395)\end{array}$ & $\begin{array}{c}-0.0926 * * \\
(0.0454)\end{array}$ & $\begin{array}{l}-0.0831 * \\
(0.0451)\end{array}$ & $\begin{array}{c}-0.1864 * * * \\
(0.0682)\end{array}$ & $\begin{array}{c}-0.0559 * * * \\
(0.0102)\end{array}$ & $\begin{array}{c}-0.1210^{* * *} \\
(0.0132)\end{array}$ \\
\hline Firm Fixed Effects Included (no) & $\begin{array}{l}-0.0340 \\
(0.0242)\end{array}$ & $\begin{array}{l}-0.0232 \\
(0.0262)\end{array}$ & $\begin{array}{l}-0.0044 \\
(0.0186)\end{array}$ & $\begin{array}{l}-0.0019 \\
(0.0221)\end{array}$ & $\begin{array}{c}-0.0062 * * * \\
(0.0020)\end{array}$ & $\begin{array}{c}0.0166 \\
(0.0124)\end{array}$ \\
\hline Time Fixed Effects Included (no) & $\begin{array}{l}0.0742 * \\
(0.0382)\end{array}$ & $\begin{array}{c}0.0783 * * \\
(0.0386)\end{array}$ & $\begin{array}{c}0.1049 * * * \\
(0.0332)\end{array}$ & $\begin{array}{c}0.0418 \\
(0.0453)\end{array}$ & $\begin{array}{c}0.0330^{* * *} \\
(0.0100)\end{array}$ & $\begin{array}{c}0.0378^{* * *} \\
(0.0130)\end{array}$ \\
\hline
\end{tabular}


Table II

(Continued)

\begin{tabular}{|c|c|c|c|c|c|c|}
\hline & (1) & $(2)$ & (3) & (4) & (5) & (6) \\
\hline \multicolumn{7}{|l|}{ Control Variables in Primary Studies } \\
\hline Control for Profitability (no) & $\begin{array}{c}0.1238 * * * \\
(0.0410)\end{array}$ & $\begin{array}{c}0.1123 * * * \\
(0.0432)\end{array}$ & $\begin{array}{c}0.1529 * * * \\
(0.0429)\end{array}$ & $\begin{array}{c}0.0723 * * \\
(0.0347)\end{array}$ & $\begin{array}{c}0.1077 * * * \\
(0.0208)\end{array}$ & $\begin{array}{c}0.1220^{* * *} \\
(0.0206)\end{array}$ \\
\hline Control for Size (no) & $\begin{array}{c}0.1568 * * * \\
(0.0573)\end{array}$ & $\begin{array}{c}0.1537 * * * \\
(0.0580)\end{array}$ & $\begin{array}{l}0.1054^{*} \\
(0.0539)\end{array}$ & $\begin{array}{c}0.0516 \\
(0.0503)\end{array}$ & $\begin{array}{c}-0.0700^{* * *} \\
(0.0124)\end{array}$ & $\begin{array}{l}-0.0137 \\
(0.0168)\end{array}$ \\
\hline Control for Firm Growth (no) & $\begin{array}{c}-0.1817 * * * \\
(0.0321)\end{array}$ & $\begin{array}{c}-0.2306^{* * * *} \\
(0.0421)\end{array}$ & $\begin{array}{c}-0.2319 * * * \\
(0.0404)\end{array}$ & $\begin{array}{c}-0.1390 * * * \\
(0.0301)\end{array}$ & $\begin{array}{c}-0.1317^{* * *} \\
(0.0198)\end{array}$ & $\begin{array}{c}-0.1652^{* * *} \\
(0.0232)\end{array}$ \\
\hline Control for Collateral (no) & $\begin{array}{c}-0.2666^{* * *} \\
(0.0596)\end{array}$ & $\begin{array}{c}-0.2826 * * * \\
(0.0604)\end{array}$ & $\begin{array}{c}-0.2257 * * * \\
(0.0540)\end{array}$ & $\begin{array}{c}-0.1206^{* *} \\
(0.0574)\end{array}$ & $\begin{array}{c}-0.0061^{* * *} \\
(0.0020)\end{array}$ & $\begin{array}{c}-0.0574^{* *} \\
(0.0285)\end{array}$ \\
\hline Control for Inflation (no) & $\begin{array}{c}0.1047 * * * \\
(0.0370)\end{array}$ & $\begin{array}{c}0.1405^{* * *} \\
(0.0430)\end{array}$ & $\begin{array}{c}0.1219 * * * \\
(0.0383)\end{array}$ & $\begin{array}{c}0.1116^{* *} \\
(0.0525)\end{array}$ & $\begin{array}{c}0.0332 * * * \\
(0.0100)\end{array}$ & $\begin{array}{c}0.0380 * * * \\
(0.0130)\end{array}$ \\
\hline Control for Industry-Typical Leverage (no) & $\begin{array}{c}0.2226 * * * \\
(0.0396)\end{array}$ & $\begin{array}{c}0.2356 * * * \\
(0.0385)\end{array}$ & $\begin{array}{c}0.2149 * * * \\
(0.0372)\end{array}$ & $\begin{array}{c}0.1184 * * * \\
(0.0325)\end{array}$ & $\begin{array}{c}0.0984 * * * \\
(0.0131)\end{array}$ & $\begin{array}{c}0.0867 * * * \\
(0.0150)\end{array}$ \\
\hline \multicolumn{7}{|l|}{ Data Sample Characteristics } \\
\hline Average Sample Year & & & $\begin{array}{l}-0.000997 \\
(0.00171)\end{array}$ & $\begin{array}{l}-0.00302 \\
(0.00473)\end{array}$ & $\begin{array}{c}7.11 \mathrm{e}-05 \\
(5.75 \mathrm{e}-05)\end{array}$ & $\begin{array}{c}0.000118 * * * \\
(3.33 \mathrm{e}-05)\end{array}$ \\
\hline \multicolumn{7}{|l|}{ Publication Selection } \\
\hline Primary Standard Error & & & $\begin{array}{c}0.3911 \\
(0.3089) \\
\end{array}$ & $\begin{array}{c}0.1426 \\
(0.3264) \\
\end{array}$ & $\begin{array}{c}1.1496 * * * \\
(0.2267) \\
\end{array}$ & $\begin{array}{c}0.9614 * * * \\
(0.2055) \\
\end{array}$ \\
\hline Database dummies included in meta-regression & No & No & No & Yes & No & Yes \\
\hline Number of primary estimations & 1012 & 1012 & 1012 & 1012 & 984 & 984 \\
\hline Adj. $R^{2}$ & 0.144 & 0.162 & 0.194 & 0.318 & 0.470 & 0.660 \\
\hline
\end{tabular}


The increase in the $\mathrm{R}^{2}$ in column (4) compared to that reported in column (3) highlights the additional explanatory power of a specification including database fixed effects. There is a slight change in the magnitude of the coefficients in our meta-regression. Even so, inferences are affected for some variables. This does not come as a surprise because several databases are used by only one primary study. As some study characteristics vary only rarely within studies, database effects remove an important share of variation from our meta-data.

It seems obvious to exploit potential efficiency gains in the meta-regression. A starting point is the appropriate treatment of the heteroskedasticity inherent to meta-analyses. Inferences in specifications (1) - (4) are based on OLS estimation with standard errors robust against heteroskedasticity using the Huber-White sandwich formula. Although this technique generally produces consistent coefficient estimates with correctly estimated standard errors, it is not at all the most efficient technique feasible given that information on the nature of the heteroskedasticity is readily available. In our meta-sample, the variance of reported primary marginal tax effects is generally known. This information is the natural candidate to define a more efficient weighting scheme for the meta-regression.

Therefore, as it is the standard in meta-studies (cf. Stanley (2008)), we directly address the heteroskedasticity by using weighted least squares (WLS) techniques. Precisely, in columns (5) and (6) of Table II, observed primary estimates, i.e. the meta-regression observations, are weighted with the inverse of their standard error before applying standard OLS. ${ }^{13}$ By giving

\footnotetext{
${ }^{13}$ The number of observations falls slightly because in a few cases primary studies do not provide information on standard errors.
} 
precise and reliable observations a greater influence, the meta-regression estimation becomes much more precise (in this line of reasoning, see, e.g., Greene (2003): 225). For this reason, columns (5) and (6) are our most preferred specification. For most of our explanatory variables, we find an impact on the marginal tax rate effect of debt financing, which is qualitatively very similar to what we found in the OLS estimations.

The results in column (6) show that we are able to identify statistically significant effects of various study characteristics, even in the presence of database fixed effects. Identification of the impact of study features that do rarely vary across studies using the same database, however, remains weak. Furthermore, database effects also remove an important share of between-study variation. Because the variation in empirical specifications between studies is an important information source in a meta-analysis, we subsequently discuss results of both specifications with and without control for database fixed effects.

For a detailed discussion of the results, it is helpful to begin with the benchmark study, which is implicitly defined by the specification of our meta-regression equation. The benchmark study is a hypothetical primary analysis of the tax effect on corporate debt policy, and the explanatory dummy variables included in the meta-regression reflect deviations from this particular benchmark specification. Accordingly, we are able to carefully predict a typical marginal tax effect for such a hypothetical benchmark analysis (and any possible enhancements). For this purpose, we further take into account the constant of the meta-regression equation and the sample mean of the two continuously defined variables Average Sample Year and Primary 
Standard Error. Considering, for example, specification (5), we finally get a predicted marginal tax effect of about $0.143 .{ }^{14}$ Hence, the hypothetical benchmark study predicts the debt-to-asset ratio to increase by 0.143 percentage points if the tax rate rises by one percentage point. Note that the benchmark specification expected to yield such a result displays the study characteristics denoted in brackets on the left hand side of Table II. While almost no specific primary study in our meta-sample fulfills all characteristics of the benchmark case, the predicted marginal tax effect for this hypothetical case, however, is a good starting point for a systematic discussion of the meta-regression results.

We begin the discussion of the meta-regression results depicted in columns (5) and (6) of Table II with a look at the definition of the tax measure. We distinguish the three common proxies for the marginal tax incentive. In comparison to the use of the statutory tax rate, reported tax effects are significantly higher if simulated marginal tax rates are used. In comparison to, for example, the marginal tax effect of about 0.143 predicted for the hypothetical benchmark study, the simulated marginal tax rates yields estimates that almost double the benchmark values. By contrast, the estimates are smaller if primary capital structure regressions employ average tax rates as opposed to statutory tax rates. These apparent differences highlight the importance of a thoughtful selection of the tax measure to be used. Because they at best approximate the truly perceived marginal tax incentive to finance with debt, simulated tax rates identify the most pronounced empirical impact. Conceptually, average tax rates are less sophisticated than

\footnotetext{
${ }^{14}$ For specification (5), a constant of about -0.1059 is estimated. The mean value of the Average Sample Year amounts to 1995.088 and the mean value of the Primary Standard Error is 0.093.
} 
simulated tax rates. Nevertheless, they are still more refined as compared to statutory tax rates. But without further precautions, average tax rates introduce serious endogeneity into capital structure regressions as they are directly affected by past and current financial decisions. We interpret the significantly negative ATR dummy coefficient in column (6) to reflect the downward bias in reported tax coefficients due to endogeneity, which remains unaddressed in many primary studies. ${ }^{15}$

Moreover, we consider the influence of characteristics of the debt items. In column (6), we observe higher marginal tax effects if primary estimates refer to long-term debt. An explanation might be that such long-term debt carries higher amounts of tax-deductible interest. There are, however, arguments for long term debt to be more sluggish and thus less sensitive to temporarily changing tax incentives. ${ }^{16}$ Still, the additional tax sensitivity of long-term debt which we identify is very tiny and economically almost insignificant. Furthermore, we find that the tax effect is slightly smaller if debt is measured at book values rather than at market values. This result however is not robust if unobserved heterogeneity between databases is controlled for.

Regarding the influence of the econometric specification of the primary analyses, our metaregression confirms that estimated tax coefficients are significantly smaller if a dynamic specification is chosen. This is in accordance with our prediction because the tax coefficient found in a dynamic specification reflects only the short-term response to taxes. However, in the

\footnotetext{
${ }^{15}$ Rather than taking into account future profitability, average tax rates are affected by current profitability. Accordingly, Booth et al. (2001: 118) point out that the average tax rate might be an alternative measure of profitability. This can also explain why the average-tax-rate tends to have a negative effect on debt ratios.

${ }^{16}$ Some studies, e.g. Gordon and Lee (2001), indeed identify stronger tax effects for short term debt, but their findings do not translate into our meta-regression results, which reflect evidence from a large number of estimates.
} 
presence of adjustment costs, the total effect will be higher in the long-term. When taking into account recent evidence on the adjustment speed of capital structures, our results suggest that long-term tax effects estimated in dynamic specifications are higher compared to evidence based on static specifications. ${ }^{17}$

Furthermore, we find that reported tax coefficients generally are only slightly affected by the inclusion of firm fixed effects in capital structure regressions. While column (5) suggests that controlling for firm fixed effects is associated with a statistically significant but small reduction of marginal tax effects, this finding is not robust against control for database fixed effects. Apparently, in numerous studies, the identifying variation in tax rates is not exclusively between firms. Accounting for unobserved time constant firm heterogeneity does not necessarily prevent or significantly hamper the isolation of partial tax effects on the corporate debt ratio. At the same time, there is no evidence for important omitted variable bias, if the fixed firm effects are not modeled. This is a somewhat comforting result for empirical researchers dealing with tax effects on corporate debt policy. The qualifications made by Lemmon et al. (2008) on the time persistence of corporate capital structures appear less discouraging, given that there seems to be sufficient "space” left for reliably identifiable tax effects.

Instead, the effect of leaving common time trends unmodeled in capital structure regressions turns out to be much more important for reported tax coefficients. Column (5) suggests that

\footnotetext{
${ }^{17}$ Let us, for example, assume the typical marginal tax effect predicted for our benchmark case of about 0.143 . In the case of a dynamic specification, the short-run effect is predicted to amount to only 0.087, but the long-run tax effect is significantly higher. Take, for example, the speed of adjustment found by Huang and Ritter (2009) of about $17-23 \%$. Accordingly, the long-run tax effect is approximately 5.9 - 4.4 times higher than the short-run effect. Then, in our case, the long-run tax effect ranges between 0.38 - 0.51 .
} 
holding time series influences constant significantly increases the identified marginal tax effect on the debt ratio by 0.033 percentage-points on average. The cross-sectional variation in tax rates between firms or countries not only allows for the identification of tax effects when time-series effects are held constant: Not taking these time effects into account seems, on average, to abet an underestimation of the partial tax effect on corporate capital structure. Interestingly, direction and magnitude of this bias as identified in our meta-regression in column (5) almost exactly correspond to earlier findings reported by Graham (1999).

Generally, empirical studies include a rich set of explanatory variables to isolate unbiased partial effects on the debt ratio. Six important non-tax determinants of capital structure are identified by Frank and Goyal (2007). Our meta-regression results in columns (5) and (6) suggest that the selection of non-tax control variables is indeed important for reported tax effects on corporate debt policy. We find that disregarding one of the six core variables listed in Frank and Goyal (2007) significantly affects reported tax effects. Controlling for firm size, collateral or firm growth is associated with smaller primary estimates of the marginal tax effects on the corporate debt ratio. The inclusion of indicators for firm profit, inflation and industry-specific leverage into the capital structure regressions raises reported tax effects. In particular, the positive impact of including profitability as a control variable does not come unexpected. Assuming that profit is negatively related to leverage (see, e.g., Titman and Wessels (1988); Rajan and Zingales (1995)) but generally correlates positively with the firm-specific tax rate, there should be a downward bias in reported tax effects if firm profitability is omitted. That is exactly what the respective meta-regression coefficient tells. 
As regards the remaining five determinants identified in Frank and Goyal (2007), we refrain from generalizing on the identified meta-dummy coefficients and do not confront them with any expected effects of variable inclusion or omission because either the sign of the determinants' effect on debt policy is ambiguous and empirically uncertain ex ante, or the way these variables correlate with the tax rate is rather unclear. Furthermore, a qualification might apply: The metadummy coefficients in Table II implicitly assume that the effect of controlling for a determinant is fully independent of the set of controls already included in the capital structure regression. This, however, need not necessarily be the case. While we therefore tend to interpret these specific results with adequate caution, we are still convinced that the identified meta-coefficients yield valuable insight on the importance of selected non-tax controls. In particular, we take note of the empirical finding that controlling for the core determinants ceteris paribus has significant consequences for the isolated tax effects. The effects are also qualitatively quite important. Controlling, e.g., for profitability leads to reported tax effects that are $75 \%$ higher compared to the benchmark case in column (5).

As regards underlying data characteristics, the respective coefficient in column (6) suggests that reported marginal tax effects seem to rise with an increasing average sample year. The effect size, however, is very tiny. Furthermore, the significantly positive relationship between primary tax coefficients and their associated standard error indeed hints at the presence of publication selection for significantly positive tax effects on debt. Put differently, to a certain extent specification-searching and publication bias, induced by editors' and authors' tendencies to look 
for positive and statistically significant estimates of the tax effect on the corporate debt ratio, seems to be present in the literature.

Generally, the regression results depict significant influence of study characteristics on estimates for the marginal tax effect. While the marginal tax effect for the hypothetical benchmark case assumed in column (5) amounts to 0.143, the results differ significantly, if more refined specifications are chosen. Let us, for example, assume a study that deviates from the benchmark case with respect to all study characteristics that prove to be significant in regression (5) of Table II, with the exception of keeping a statutory tax rate and a static specification. Then, the predicted marginal tax effect is 0.195 . Now, let us vary the proxy for the tax incentive. If a simulated marginal tax rate is substituted for the statutory tax rate, the predicted tax effect rises to 0.302 .

\section{B. Robustness Analyses}

In Table III we provide some robustness checks. While specifications (4) and (6) of Table II controlled for database effects, in column (1) of Table III we consider a full set of study fixed effects to capture unobserved characteristics that have affected all estimates taken from the same study. For example, estimates from a certain study might share the same data sampling procedure. The results in column (1) show that including study fixed effects in our metaregression has consequences for the identification of some study characteristics. While the results on the impact of the different proxies for the marginal tax incentive are qualitatively unaffected, the impact of econometric specifications and control variables used in primary 


\section{Table III}

\section{Meta-Regression of Reported Marginal Tax Effects on Debt Ratios, Robustness Analyses}

Regressions of the marginal tax effect found in primary studies on respective study characteristics. All study/model characteristics are coded as dummy variables (except Average Sample Year and Primary Standard Error). Thus, a base model represents the characteristics redundant to the variables explicitly included. The benchmark characteristics are indicated in parentheses for each study dimension. Estimated coefficients of the dummies indicate the effect on primary marginal effects of choosing a characteristic in lieu of the base specification. All regressions include a constant (not reported). The regressions are based on Sample A. All regressions are from WLS estimation. Heteroskedasticity robust standard errors in parentheses; $* * * / * * / *$ denotes significance at the $1 \% / 5 \% / 10 \%$ level. Column (1) includes a full set of study dummies. In column (2) standard errors are clustered at the study level. Columns (3) and (4) consider only primary estimates from studies published in journals or books. Columns (5) and (6) include only primary tax effects that are significant at the five percent level.

\begin{tabular}{|c|c|c|c|c|c|c|}
\hline & \multirow{2}{*}{$\begin{array}{c}\begin{array}{c}\text { Study } \\
\text { Dummies }\end{array} \\
(1) \\
\end{array}$} & \multirow{2}{*}{$\begin{array}{c}\text { Clustered } \\
\text { Standard Errors } \\
(2)\end{array}$} & \multicolumn{2}{|c|}{ Published Studies } & \multicolumn{2}{|c|}{ Significant Estimates } \\
\hline & & & (3) & (4) & (5) & (6) \\
\hline \multicolumn{7}{|l|}{ Proxies for the Marginal Tax Incentive } \\
\hline SMTR (Statutory Tax Rate) & $\begin{array}{c}0.1325^{* * *} \\
(0.0312)\end{array}$ & $\begin{array}{c}0.0567 * * \\
(0.0268)\end{array}$ & $\begin{array}{c}0.1109 * * * \\
(0.0203)\end{array}$ & $\begin{array}{c}0.2629 * * * \\
(0.0293)\end{array}$ & $\begin{array}{c}0.1346 * * * \\
(0.0279)\end{array}$ & $\begin{array}{c}0.0753^{* * *} \\
(0.0165)\end{array}$ \\
\hline ATR (Statutory Tax Rate) & $\begin{array}{c}-0.0132 * * * \\
(0.0038)\end{array}$ & $\begin{array}{l}-0.0310^{*} \\
(0.0180)\end{array}$ & $\begin{array}{c}0.0207 \\
(0.0133)\end{array}$ & $\begin{array}{c}0.0813^{* *} \\
(0.0407)\end{array}$ & $\begin{array}{l}-0.0119 \\
(0.0132)\end{array}$ & $\begin{array}{c}-0.0332 * * * \\
(0.0103)\end{array}$ \\
\hline \multicolumn{7}{|l|}{ Debt Characteristics } \\
\hline Long-Term Debt (Maturity not Specified or Short-Term) & $\begin{array}{c}0.0114 * * * \\
(0.0025)\end{array}$ & $\begin{array}{l}0.0078^{*} \\
(0.0045)\end{array}$ & $\begin{array}{c}0.0059 \\
(0.0051)\end{array}$ & $\begin{array}{c}0.0105^{* * *} \\
(0.0027)\end{array}$ & $\begin{array}{c}-0.0145 \\
(0.0109)\end{array}$ & $\begin{array}{c}0.0100 * * * \\
(0.0033)\end{array}$ \\
\hline Debt Measured at Book Values (Market Values) & $\begin{array}{c}0.0003 \\
(0.0012)\end{array}$ & $\begin{array}{l}-0.0006 \\
(0.0010)\end{array}$ & $\begin{array}{c}-0.0090 \\
(0.0108)\end{array}$ & $\begin{array}{c}0.0030 \\
(0.0085)\end{array}$ & $\begin{array}{l}-0.0041 \\
(0.0041)\end{array}$ & $\begin{array}{c}-0.0001 \\
(0.0019)\end{array}$ \\
\hline Econometric Specification of Primary Studies & & & & & & \\
\hline Dynamic Specification (Static Specification) & $\begin{array}{l}-0.0084 \\
(0.0157)\end{array}$ & $\begin{array}{c}-0.1210 * * * \\
(0.0202)\end{array}$ & $\begin{array}{c}-0.0265^{*} \\
(0.0144)\end{array}$ & $\begin{array}{c}0.0567 * * \\
(0.0265)\end{array}$ & $\begin{array}{c}-0.0813^{* * * *} \\
(0.0150)\end{array}$ & $\begin{array}{c}-0.1244 * * * \\
(0.0135)\end{array}$ \\
\hline Firm Fixed Effects Included (no) & $\begin{array}{l}-0.0037 \\
(0.0123)\end{array}$ & $\begin{array}{c}0.0166 \\
(0.0156)\end{array}$ & $\begin{array}{c}-0.0184 * \\
(0.0108)\end{array}$ & $\begin{array}{c}-0.0199 \\
(0.0162)\end{array}$ & $\begin{array}{c}-0.0071^{* *} \\
(0.0031)\end{array}$ & $\begin{array}{c}0.0299 * * \\
(0.0125)\end{array}$ \\
\hline Time Fixed Effects Included (no) & $\begin{array}{c}0.0132 \\
(0.0127)\end{array}$ & $\begin{array}{c}0.0378 * * \\
(0.0154)\end{array}$ & $\begin{array}{l}0.0185^{*} \\
(0.0102)\end{array}$ & $\begin{array}{c}0.0438 * * \\
(0.0216)\end{array}$ & $\begin{array}{c}0.0568 * * * \\
(0.0137)\end{array}$ & $\begin{array}{l}0.0285^{*} \\
(0.0145)\end{array}$ \\
\hline
\end{tabular}


Table III

(Continued)

\begin{tabular}{|c|c|c|c|c|c|c|}
\hline & (1) & (2) & (3) & (4) & (5) & (6) \\
\hline \multicolumn{7}{|l|}{ Control Variables in Primary Studies } \\
\hline Control for Profitability (no) & $\begin{array}{c}0.0138 \\
(0.0259)\end{array}$ & $\begin{array}{c}0.1220^{* * *} \\
(0.0324)\end{array}$ & $\begin{array}{c}0.0462 * * \\
(0.0188)\end{array}$ & $\begin{array}{c}0.1485^{* * *} \\
(0.0236)\end{array}$ & $\begin{array}{c}0.1774 * * * \\
(0.0218)\end{array}$ & $\begin{array}{c}0.1180 * * * \\
(0.0172)\end{array}$ \\
\hline Control for Size (no) & $\begin{array}{c}0.0343 \\
(0.0274)\end{array}$ & $\begin{array}{l}-0.0137 \\
(0.0218)\end{array}$ & $\begin{array}{c}-0.0411^{* * *} \\
(0.0134)\end{array}$ & $\begin{array}{c}-0.0650 * * * \\
(0.0237)\end{array}$ & $\begin{array}{c}0.0132 \\
(0.0210)\end{array}$ & $\begin{array}{c}-0.0694^{* *} \\
(0.0285)\end{array}$ \\
\hline Control for Firm Growth (no) & $\begin{array}{l}-0.0199 \\
(0.0147)\end{array}$ & $\begin{array}{c}-0.1652 * * * \\
(0.0544)\end{array}$ & $\begin{array}{c}-0.0415^{* * *} \\
(0.0124)\end{array}$ & $\begin{array}{l}-0.0249 * \\
(0.0147)\end{array}$ & $\begin{array}{c}-0.1523 * * * \\
(0.0274)\end{array}$ & $\begin{array}{c}-0.1640 * * * \\
(0.0259)\end{array}$ \\
\hline Control for Collateral (no) & $\begin{array}{c}0.0018 \\
(0.0158)\end{array}$ & $\begin{array}{l}-0.0574 \\
(0.0500)\end{array}$ & $\begin{array}{l}-0.0089 \\
(0.0130)\end{array}$ & $\begin{array}{c}-0.0648 * \\
(0.0349)\end{array}$ & $\begin{array}{c}-0.0480^{*} \\
(0.0250)\end{array}$ & $\begin{array}{c}0.0470 \\
(0.0350)\end{array}$ \\
\hline Control for Inflation (no) & $\begin{array}{c}0.0134 \\
(0.0127)\end{array}$ & $\begin{array}{c}0.0380 * * \\
(0.0154)\end{array}$ & $\begin{array}{c}0.0906 * * * \\
(0.0136)\end{array}$ & $\begin{array}{c}0.0564 * * \\
(0.0235)\end{array}$ & $\begin{array}{c}0.0570^{* * *} \\
(0.0137)\end{array}$ & $\begin{array}{c}0.0288 * * \\
(0.0145)\end{array}$ \\
\hline Control for Industry-Typical Leverage (no) & $\begin{array}{l}-0.0112 \\
(0.0151)\end{array}$ & $\begin{array}{c}0.0867 * * * \\
(0.0250)\end{array}$ & $\begin{array}{c}0.0476 * * * \\
(0.0115)\end{array}$ & $\begin{array}{c}0.0869 * * * \\
(0.0178)\end{array}$ & $\begin{array}{c}0.1504 * * * \\
(0.0217)\end{array}$ & $\begin{array}{c}0.0891 * * * \\
(0.0152)\end{array}$ \\
\hline \multicolumn{7}{|l|}{ Data Sample Characteristics } \\
\hline Average Sample Year & $\begin{array}{c}0.000118 * * * \\
(3.38 \mathrm{e}-05)\end{array}$ & $\begin{array}{c}0.000118 * * * \\
(2.73 e-06)\end{array}$ & $\begin{array}{c}0.00105 \\
(0.000720)\end{array}$ & $\begin{array}{l}-0.000391 \\
(0.00233)\end{array}$ & $\begin{array}{c}0.000102 * * \\
(5.04 \mathrm{e}-05)\end{array}$ & $\begin{array}{c}0.000148 * * * \\
(9.44 \mathrm{e}-06)\end{array}$ \\
\hline \multicolumn{7}{|l|}{ Publication Selection } \\
\hline Primary Standard Error & $\begin{array}{c}1.0186 * * * \\
(0.2197) \\
\end{array}$ & $\begin{array}{c}0.9614^{* *} \\
(0.4352) \\
\end{array}$ & $\begin{array}{c}0.8908 * * * \\
(0.1987) \\
\end{array}$ & $\begin{array}{c}0.3955^{* *} \\
(0.1802) \\
\end{array}$ & $\begin{array}{c}2.3259 * * * \\
(0.4060) \\
\end{array}$ & $\begin{array}{c}2.0153 * * * \\
(0.3802) \\
\end{array}$ \\
\hline Database Dummies Included in Meta-Regression & No & Yes & No & Yes & No & Yes \\
\hline Study Dummies Included in Meta-Regression & Yes & No & No & No & No & No \\
\hline Number of Primary Estimations & 984 & 984 & 581 & 581 & 589 & 589 \\
\hline Adj. $R^{2}$ & 0.745 & 0.660 & 0.495 & 0.623 & 0.593 & 0.726 \\
\hline
\end{tabular}


studies is no longer significant at conventional levels. Meanwhile, the signs of the coefficients remain mostly unchanged. This hints at identification difficulties that arise if study characteristics vary indeed between studies, but only rarely within studies. Carefully considering our results, we argue that the study fixed effects are associated with identification difficulties while we do, however, not feel that the results point at serious omitted variable biases in estimations with unmodeled study fixed effects.

In column (2) of Table III we take into account the dependency of primary estimates taken from the same study by using standard errors clustered at the study level. Results turn out to be again quite robust.

In column (3) and (4) of Table III the focus is exclusively on published studies. These regressions might give some further indication about the possible presence of publication biases. Furthermore, as most of the published articles in the meta-sample appeared in high-quality journals, selecting only published estimates into the meta-sample is also an effective quality filter. In columns (5) and (6) we consider only primary tax estimates that were statistically significant at the five percent level. Still, looking exclusively at published studies or respectively on significant primary estimates implies a sharp reduction of the meta-sample which drops by about $40 \%$. 
Generally, the regression results presented in columns (3) - (6) confirm most of our findings based on the full sample. Regarding the influence of the tax measures, the results confirm a significantly higher tax coefficient if simulated marginal tax rates are used. Interestingly, based on the estimates taken from the published studies, we do not find any negative effect on reported tax coefficients if average tax rates are employed. By contrast in column (4), where we include database fixed effects in the meta-regression, the meta-coefficient for the average tax rate suggests that identified tax effects are even significantly higher as compared to statutory tax rates. One may speculate that the review process in the run-up to publication often forces a more careful treatment of the endogeneity problems associated with average tax rates, thereby eliminating downwardly biased tax effect estimates.

\section{Exclusion of Multinational Subsidiaries}

The tax incentives and determinants of capital structures might be very distinct for foreign subsidiaries, as compared to domestic firms. In this section, we therefore exclude all 352 primary tax effect estimates that exclusively refer to subsidiaries of multinational firms from the metaregression analysis. We are thus left with Sample B as described in Section IV, containing 632 observations. Table IV presents regression results using this subsample of primary estimates. Specification (1) in Table IV considers our basic set of meta-variables, in column (2) we also control for database fixed effects. Generally, the results are very similar to those found for the full meta-sample in columns (6) and (7) of Table II. 


\section{Table IV}

\section{Meta-Regression of Reported Tax Effects on Debt Ratios, Excluding Multinational Subsidiaries}

Regressions of the marginal tax effect found in primary studies on respective study characteristics. All study/model characteristics are coded as dummy variables (except Average Sample Year and Primary Standard Error). Thus, a base model represents the characteristics redundant to the variables explicitly included. The benchmark characteristics are indicated in parentheses for each study dimension. Estimated coefficients of the dummies indicate the effect on primary marginal effects of choosing a characteristic in lieu of the base specification. All regressions include a constant (not reported). The regressions are based on Sample B (primary estimates referring to multinational subsidiaries are excluded). All regressions are from WLS estimation. Heteroskedasticity robust standard errors in parentheses; ***/**/* denotes significance at the $1 \% / 5 \% / 10 \%$ level.

\begin{tabular}{|c|c|c|c|c|c|}
\hline & (1) & (2) & (3) & (4) & (5) \\
\hline \multicolumn{6}{|l|}{ Proxies for the Marginal Tax Incentive } \\
\hline SMTR (Statutory Tax Rate) & $\begin{array}{c}0.0838 * * * \\
(0.0211)\end{array}$ & $\begin{array}{c}0.0655^{* * *} \\
(0.0183)\end{array}$ & $\begin{array}{c}0.0974 * * * \\
(0.0177)\end{array}$ & $\begin{array}{c}0.1153^{* * *} \\
(0.0206)\end{array}$ & $\begin{array}{c}0.1115^{* * *} \\
(0.0353)\end{array}$ \\
\hline ATR (Statutory Tax Rate) & $\begin{array}{l}-0.0140 \\
(0.0101)\end{array}$ & $\begin{array}{c}-0.0389 * * * \\
(0.0101)\end{array}$ & $\begin{array}{c}-0.0333 * * * \\
(0.0088)\end{array}$ & & \\
\hline ATR is Immune to Endogeneity (Statutory Tax Rate) & & & & $\begin{array}{c}0.0042 \\
(0.0355)\end{array}$ & $\begin{array}{c}0.0042 \\
(0.0357)\end{array}$ \\
\hline ATR is Potentially Endogenous (Statutory Tax Rate) & & & & $\begin{array}{c}-0.0392 * * * \\
(0.0086)\end{array}$ & $\begin{array}{c}-0.0392 * * * \\
(0.0086)\end{array}$ \\
\hline Personal Taxes Included (Only Corporate Taxes) & & & & & $\begin{array}{c}0.0067 \\
(0.0413)\end{array}$ \\
\hline \multicolumn{6}{|l|}{ Debt Characteristics } \\
\hline Long-Term Debt (Maturity not Specified) & $\begin{array}{c}-0.0107 \\
(0.0097)\end{array}$ & $\begin{array}{c}0.0111^{* * *} \\
(0.0040)\end{array}$ & $\begin{array}{c}0.0096 * * \\
(0.0039)\end{array}$ & $\begin{array}{c}0.0102^{* * *} \\
(0.00383)\end{array}$ & $\begin{array}{c}0.0103^{* * *} \\
(0.0038)\end{array}$ \\
\hline Debt Measured at Book Values (Market Values) & $\begin{array}{c}-0.0074^{* *} \\
(0.0031)\end{array}$ & $\begin{array}{c}-0.0004 \\
(0.0012)\end{array}$ & $\begin{array}{l}-0.0005 \\
(0.0012)\end{array}$ & $\begin{array}{l}-0.0005 \\
(0.0012)\end{array}$ & $\begin{array}{l}-0.0005 \\
(0.0012)\end{array}$ \\
\hline \multicolumn{6}{|l|}{ Econometric Specification of Primary Studies } \\
\hline Dynamic Specification (Static Specification) & $\begin{array}{c}-0.0680^{* * *} \\
(0.0133)\end{array}$ & $\begin{array}{c}-0.1223 * * * \\
(0.0172)\end{array}$ & $\begin{array}{c}-0.1487 * * * \\
(0.0166)\end{array}$ & $\begin{array}{c}-0.1382 * * * \\
(0.0209)\end{array}$ & $\begin{array}{c}-0.1387 * * * \\
(0.0211)\end{array}$ \\
\hline Firm Fixed Effects Included (no) & $\begin{array}{c}-0.0057 * * * \\
(0.0020)\end{array}$ & $\begin{array}{l}0.0229 * \\
(0.0136)\end{array}$ & $\begin{array}{c}0.0021 \\
(0.0125)\end{array}$ & $\begin{array}{l}-0.0100 \\
(0.0153)\end{array}$ & $\begin{array}{c}-0.0106 \\
(0.0161)\end{array}$ \\
\hline Time Fixed Effects Included (no) & $\begin{array}{c}0.0439 * * * \\
(0.0124)\end{array}$ & $\begin{array}{c}0.0330 * * \\
(0.0154)\end{array}$ & $\begin{array}{c}0.0469 * * * \\
(0.0151)\end{array}$ & $\begin{array}{c}0.0586^{* * *} \\
(0.0187)\end{array}$ & $\begin{array}{c}0.0583^{* * *} \\
(0.0184)\end{array}$ \\
\hline
\end{tabular}


Table IV

(Continued)

\begin{tabular}{|c|c|c|c|c|c|}
\hline & (1) & (2) & (3) & (4) & (5) \\
\hline \multicolumn{6}{|l|}{ Control Variables in Primary Studies } \\
\hline Control for Profitability (no) & $\begin{array}{c}0.0864 * * * \\
(0.0275)\end{array}$ & $\begin{array}{c}0.1588^{* * *} \\
(0.0272)\end{array}$ & $\begin{array}{c}0.1966^{* * *} \\
(0.0295)\end{array}$ & $\begin{array}{c}0.1958 * * * \\
(0.0276)\end{array}$ & $\begin{array}{c}0.1925^{* * *} \\
(0.0367)\end{array}$ \\
\hline Control for Size (no) & $\begin{array}{c}-0.0639 * * * \\
(0.0148)\end{array}$ & $\begin{array}{c}0.0023 \\
(0.0306)\end{array}$ & $\begin{array}{c}0.2207 * * * \\
(0.0609)\end{array}$ & $\begin{array}{c}0.2264 * * * \\
(0.0584)\end{array}$ & $\begin{array}{c}0.2275 * * * \\
(0.0594)\end{array}$ \\
\hline Control for Firm Growth (no) & $\begin{array}{c}-0.1328 * * * \\
(0.0218)\end{array}$ & $\begin{array}{c}-0.1669 * * * \\
(0.0308)\end{array}$ & $\begin{array}{c}-0.1482 * * * \\
(0.0273)\end{array}$ & $\begin{array}{c}-0.1510 * * * \\
(0.0272)\end{array}$ & $\begin{array}{c}-0.1504^{* * *} \\
(0.0274)\end{array}$ \\
\hline Control for Collateral (no) & $\begin{array}{c}-0.0057^{* * *} \\
(0.0020)\end{array}$ & $\begin{array}{c}-0.0974 * * \\
(0.0480)\end{array}$ & $\begin{array}{c}-0.1826 * * * \\
(0.0479)\end{array}$ & $\begin{array}{c}-0.1699 * * * \\
(0.0491)\end{array}$ & $\begin{array}{c}-0.1676^{* * *} \\
(0.0519)\end{array}$ \\
\hline Control for Inflation (no) & $\begin{array}{c}0.0440 * * * \\
(0.0124)\end{array}$ & $\begin{array}{c}0.0332 * * \\
(0.0154)\end{array}$ & $\begin{array}{c}0.0471^{* * *} \\
(0.0151)\end{array}$ & $\begin{array}{c}0.0588 * * * \\
(0.0187)\end{array}$ & $\begin{array}{c}0.0585 * * * \\
(0.0184)\end{array}$ \\
\hline Control for Industry-Typical Leverage (no) & $\begin{array}{c}0.0906 * * * \\
(0.0150)\end{array}$ & $\begin{array}{c}0.0857 * * * \\
(0.0215)\end{array}$ & $\begin{array}{c}0.1402 * * * \\
(0.0225)\end{array}$ & $\begin{array}{c}0.1381^{* * *} \\
(0.0225)\end{array}$ & $\begin{array}{c}0.1395 * * * \\
(0.0250)\end{array}$ \\
\hline \multicolumn{6}{|l|}{ Data Sample Characteristics } \\
\hline $\begin{array}{l}\text { Average Sample Year } \\
\text { Loss Making Companies Excluded (not Excluded) }\end{array}$ & $\begin{array}{c}7.73 e-05 \\
(5.47 \mathrm{e}-05)\end{array}$ & $\begin{array}{c}0.000118 * * * \\
(3.34 \mathrm{e}-05)\end{array}$ & $\begin{array}{c}0.000117 * * * \\
(3.38 \mathrm{e}-05) \\
0.2595 * * * \\
(0.0571)\end{array}$ & $\begin{array}{c}0.000117 * * * \\
(3.36 \mathrm{e}-05) \\
0.2657 * * * \\
(0.0539)\end{array}$ & $\begin{array}{c}0.000117 * * * \\
(3.36 \mathrm{e}-05) \\
0.2669 * * * \\
(0.0552)\end{array}$ \\
\hline \multicolumn{6}{|l|}{ Publication Selection } \\
\hline Primary Standard Error & $\begin{array}{c}0.7651^{* * *} \\
(0.2675) \\
\end{array}$ & $\begin{array}{c}0.7200 * * * \\
(0.2588)\end{array}$ & $\begin{array}{c}0.6713 * * * \\
(0.2512)\end{array}$ & $\begin{array}{c}0.5888 * * \\
(0.2491)\end{array}$ & $\begin{array}{c}0.5898 * * \\
(0.2503)\end{array}$ \\
\hline Database Dummies Included in Meta-Regression & No & Yes & Yes & Yes & Yes \\
\hline Number of Primary Estimations & 632 & 632 & 632 & 632 & 632 \\
\hline Adj. $R^{2}$ & 0.457 & 0.657 & 0.684 & 0.684 & 0.684 \\
\hline
\end{tabular}


The meta-regression results again allow predicting marginal tax effects that account for potential misspecification biases. Let us, for example, consider the results of column (1) of Table IV. Then, a marginal tax effect of 0.201 is predicted for a hypothetical study where the statutory tax rate, a static econometric specification and all other characteristics that prove to be statistically significant are chosen. Yet, if a simulated marginal tax rate is considered, we obtain a significantly larger predicted marginal tax effect on debt financing of about 0.285.

Given the clear focus of the subsample, we proceed with a thorough analysis of how the approximation of the marginal tax incentive affects tax effects estimated in the literature. For this purpose, we define some extra dummy variables. First, in column (3) we consider an additional dummy Loss Making Firm Excluded that marks those primary analyses which rely on statutory rates but try to overcome related shortcomings by excluding loss-making companies from the data sample used by the respective study. Put differently, we identify primary studies that do not consider firms that are likely to be tax exhausted. Our regression results provide striking evidence that, in fact, marginal tax effects are more pronounced if loss making firms are excluded from the sample considered by the primary analysis.

Second, in column (4) we distinguish between studies using effective average tax rates that explicitly cope with endogeneity concerns (ATR Immune to Endogeneity) and others that do not address this problem (ATR is Potentially Endogenous). ${ }^{18}$

\footnotetext{
${ }^{18}$ Some studies employing average tax rates (e.g. Lasfer (1995); Charalambakis et al. (2008)) neutralize the impact of interest deductions by putting tax payments derived from pre-interest profits in the numerator and by consistently relating it to those before financing profits.
} 
Our results support the view that the negative effect found for average tax rates is driven by a negative downward bias due to endogeneity. While we find a statistically smaller tax effect if average tax rates are potentially endogeneous, average tax rates immune to endogeneity do not exert significant differences in tax effects, compared to statutory tax rates.

Finally, we code a dummy Personal Taxes which takes on a value of one, if personal taxes are included in the tax term and zero otherwise. While the interest deductibility creates the corporate tax incentive to use debt, shareholder taxation often differentiates between the types of capital, as well. Still, the tax data used in the primary literature mostly reflects the pure corporate tax advantage of debt. The seminal work by Miller (1977), however, suggests that both corporate profit taxes and personal capital income taxes affect capital structure choices. If the personal tax status of capital providers is known, capital structures are supposed to adjust to the afterpersonal-tax benefit of debt. ${ }^{19}$ Some studies have included personal taxes in the measure for the marginal tax incentive to use debt financing. In column (5) we test whether estimated tax effects differ if the tax measure also includes personal taxes imposed on capital income. Yet, we do not find any statistically significant impact of the inclusion of personal taxes in the tax rate proxy.

\section{Tax Response of Multinational Firms}

In recent years, the debt policy of multinational firms has attracted increasing attention in the literature. Therefore, we run some further meta-regressions on Sample C of our meta-data

\footnotetext{
${ }^{19}$ Since in most countries personal taxes imposed on interest income are equal or even higher than the taxes on dividends or capital gains, personal taxes are typically associated with a tax penalty of debt (Graham (1999)).
} 
containing tax effect estimates derived on the basis of pure multinational subsidiary data. Table V shows the respective meta-regression results. In columns (1) to (4) we again regress the marginal tax effects found in primary studies on a set of study characteristics. ${ }^{20}$ While regressions shown in columns (1) and (2) do not include the 101 pure profit shifting effects, they are additionally considered in columns (3) and (4), which themselves only differ with respect to the inclusion of database effects. To conclude, columns (3) and (4) present the most extended and complete meta-regression specifications. We primarily rely on these results when turning to interpretations. However, most coefficients are robust in sign and significance across columns (1) to (4) in Table V.

Interestingly, in the case of multinational firms we find that identified tax effects on debt policy are more pronounced if an average tax rate is considered instead of a statutory tax rate. An explanation for this finding might be that, in this Sample C, most primary estimates which refer to average tax rates successfully cope with the endogeneity concern. ${ }^{21}$ Moreover, the important cross-country tax code differences are implicitly captured by average tax rates.

\footnotetext{
${ }^{20}$ Compared to the specifications run on Samples A and B in subsections A to C, we generally cannot control for debt-maturity, the measurement of debt and the implications of a dynamic specification. There is almost no variation with respect to these properties in analyses focusing on multinational subsidiaries. For the same reason, we are not able to test whether a simulated tax rate would be associated with higher tax effects.

${ }^{21}$ In Sample C, the lion's share of primary estimates using average tax rates is from Desai et al. (2004) and Aggarwal and Kyaw (2008) who in fact have dealt with endogeneity concerns by considering host country median average tax rates.
} 
Generally, the observed international differences in corporate tax levels should affect the allocation of debt within a multinational firm. ${ }^{22}$ Multinational firms can issue bonds preferentially in high tax countries (Newberry and Dhaliwal (2001)). They might, in addition, fine-tune taxable profits of high-taxed subsidiaries by using intra-company loans (Desai et al. (2004)). To capture the distinctive features of multinational debt financing, we again extend the basic set of meta-regressors and consider some extra dummy variables.

First, we code an additional dummy variable Intra-Company Debt that marks tax effect estimates exclusively referring to inter-company loans, as opposed to third-party or total debt. ${ }^{23}$ By definition, the marginal tax effect on total debt is most pronounced, as the marginal tax effects on the two debt components, intra-company and external debt, add up. Consistently, in columns (1) to (4), the coefficient for Intra-Company Debt is significant with a negative sign.

Second, we consider the way primary studies model unobserved cross-sectional firm effects in more detail. Precisely, we distinguish whether unobserved subsidiary-fixed effects or unobserved parent-fixed effects are considered. According to the results, however, the inclusion of neither of these two types of fixed effects seems to have an impact on the identification of marginal tax effects. Instead, in accordance with our former results we find that a careful modeling of unobservable time-effects drives identified tax effects upward. Interestingly, the magnitude of this effect seems to be particularly pronounced in the case of multinational debt financing.

\footnotetext{
${ }^{22}$ While in 2009, for example, the statutory tax rate of the federal corporate income tax was $35 \%$ in the US, the corresponding tax rate was below $25 \%$ in several European countries. The corporate tax rate in, e.g., Ireland was as low as $12.5 \%$.

${ }^{23}$ By far most estimates in Sample C refer to total debt or intra-company debt, only 35 primary tax effects are derived on the basis of external debt. We therefore abstain from considering a dummy for external debt.
} 
Table V

\section{Meta-Regression of Reported Tax Effects on Debt Ratios, Multinational Subsidiaries}

Regressions of the tax effect found in primary studies on respective study characteristics. All study/model characteristics are coded as dummy variables (except Average Sample Year and Primary Standard Error). Thus, a base model represents the characteristics redundant to the variables explicitly included. The benchmark characteristics are indicated in parentheses for each study dimension. Estimated coefficients of the dummies indicate the effect on primary marginal effects of choosing a characteristic in lieu of the base specification. All regressions include a constant (not reported). All regressions are from WLS estimation. Heteroskedasticity robust standard errors in parentheses; ***/**/* denotes significance at the $1 \% / 5 \% / 10 \%$ level. The regressions are based on Sample C (only primary estimates referring to multinational subsidiaries). In columns (1) and (2) primary estimates are excluded that reflect a pure tax effect due to cross-border profit shifting. In columns (1) - (4) the dependent variable is the marginal tax effect found in primary studies; in columns (5) - (6) the dependent variable is the tax semi-elasticity of the debt ratio.

\begin{tabular}{|c|c|c|c|c|c|c|}
\hline & \multicolumn{4}{|c|}{ Marginal Tax Effects } & \multicolumn{2}{|c|}{ Tax Semi-Elasticities } \\
\hline & (1) & (2) & (3) & (4) & (5) & (6) \\
\hline \multicolumn{7}{|l|}{ Proxies for the Marginal Tax Incentive } \\
\hline ATR (Statutory Tax Rate) & $\begin{array}{c}0.1829 * * * \\
(0.0285)\end{array}$ & $\begin{array}{c}0.2133^{* * *} \\
(0.0370)\end{array}$ & $\begin{array}{c}0.1301^{* * *} \\
(0.0293)\end{array}$ & $\begin{array}{c}0.2177^{* * *} \\
(0.0426)\end{array}$ & $\begin{array}{c}0.7667 * * * \\
(0.1160)\end{array}$ & $\begin{array}{c}1.0232 * * * \\
(0.1908)\end{array}$ \\
\hline Tax Effect Controlled for Profit-Shifting (Total Tax Incentive) & & & $\begin{array}{c}-0.0340^{* *} \\
(0.0134)\end{array}$ & $\begin{array}{c}-0.0478 * * * \\
(0.0133)\end{array}$ & $\begin{array}{c}0.0291 \\
(0.0452)\end{array}$ & $\begin{array}{l}-0.0159 \\
(0.0503)\end{array}$ \\
\hline Profit-Shifting Tax Effect (Total Tax Incentive) & & & $\begin{array}{l}-0.0074 \\
(0.0118)\end{array}$ & $\begin{array}{c}-0.0259 * * \\
(0.0115)\end{array}$ & $\begin{array}{c}-0.1677^{* * *} \\
(0.0313)\end{array}$ & $\begin{array}{c}-0.2147 * * * \\
(0.0384)\end{array}$ \\
\hline Credit System (Exemption System) & & & $\begin{array}{l}-0.0017 \\
(0.0047)\end{array}$ & $\begin{array}{c}-0.0008 \\
(0.0044)\end{array}$ & $\begin{array}{l}-0.0896 \\
(0.0609)\end{array}$ & $\begin{array}{c}-0.0459 \\
(0.0287)\end{array}$ \\
\hline Debt Characteristics & & & & & & \\
\hline $\begin{array}{l}\text { Intra-Company Debt (Total Debt) } \\
\text { Econometric Specification of Primary Studies }\end{array}$ & $\begin{array}{c}-0.0920 * * * \\
(0.0166)\end{array}$ & $\begin{array}{c}-0.0919 * * * \\
(0.0173)\end{array}$ & $\begin{array}{c}-0.0784 * * * \\
(0.0161)\end{array}$ & $\begin{array}{c}-0.0681^{* * *} \\
(0.0164)\end{array}$ & $\begin{array}{c}0.1563 * * \\
(0.0615)\end{array}$ & $\begin{array}{c}0.2879 * * * \\
(0.0686)\end{array}$ \\
\hline Subsidiary Fixed Effects Included (no) & $\begin{array}{l}-0.0600^{*} \\
(0.0349)\end{array}$ & $\begin{array}{c}-0.0226 \\
(0.0436)\end{array}$ & $\begin{array}{l}-0.0540 \\
(0.0348)\end{array}$ & $\begin{array}{c}0.0014 \\
(0.0364)\end{array}$ & $\begin{array}{c}-0.4895 * * * \\
(0.1296)\end{array}$ & $\begin{array}{c}-0.0931 \\
(0.1322)\end{array}$ \\
\hline Parent Fixed Effects Included (no) & $\begin{array}{c}-0.0736^{* *} \\
(0.0329)\end{array}$ & $\begin{array}{l}-0.0693 * \\
(0.0411)\end{array}$ & $\begin{array}{c}0.0015 \\
(0.0322)\end{array}$ & $\begin{array}{c}0.0248 \\
(0.0329)\end{array}$ & $\begin{array}{c}0.0366 \\
(0.1304)\end{array}$ & $\begin{array}{c}0.0441 \\
(0.1593)\end{array}$ \\
\hline Time Fixed Effects Included (no) & $\begin{array}{c}0.1709 * * * \\
(0.0405)\end{array}$ & $\begin{array}{c}0.1837 * * * \\
(0.0431)\end{array}$ & $\begin{array}{c}0.1250^{* * *} \\
(0.0426)\end{array}$ & $\begin{array}{c}0.1422^{* * *} \\
(0.0420)\end{array}$ & $\begin{array}{c}0.5814^{* * *} \\
(0.1788)\end{array}$ & $\begin{array}{c}0.4782^{* * *} \\
(0.1775)\end{array}$ \\
\hline
\end{tabular}


Table V

(Continued)

\begin{tabular}{|c|c|c|c|c|c|c|}
\hline & (1) & (2) & (3) & (4) & (5) & (6) \\
\hline \multicolumn{7}{|l|}{ Control Variables in Primary Studies } \\
\hline Control for Profitability (no) & $\begin{array}{c}-0.0047 \\
(0.0166)\end{array}$ & $\begin{array}{l}-0.0206 \\
(0.0198)\end{array}$ & $\begin{array}{l}-0.0167 \\
(0.0117)\end{array}$ & $\begin{array}{c}-0.0328 * * \\
(0.0129)\end{array}$ & $\begin{array}{l}-0.0207 \\
(0.0233)\end{array}$ & $\begin{array}{l}-0.0179 \\
(0.0245)\end{array}$ \\
\hline Control for Size (no) & $\begin{array}{c}0.0236 \\
(0.0156)\end{array}$ & $\begin{array}{c}0.0073 \\
(0.0167)\end{array}$ & $\begin{array}{c}-0.0014 \\
(0.0112)\end{array}$ & $\begin{array}{l}-0.0011 \\
(0.0112)\end{array}$ & $\begin{array}{c}0.1029 \\
(0.0839)\end{array}$ & $\begin{array}{c}-0.0717 \\
(0.0872)\end{array}$ \\
\hline Control for Firm Growth (no) & $\begin{array}{c}-0.2211^{* * *} \\
(0.0303)\end{array}$ & $\begin{array}{c}-0.0921 * * \\
(0.0435)\end{array}$ & $\begin{array}{c}-0.1327 * * * \\
(0.0224)\end{array}$ & $\begin{array}{l}-0.0449 \\
(0.0409)\end{array}$ & $\begin{array}{l}-0.0477 \\
(0.0565)\end{array}$ & $\begin{array}{c}0.1007 \\
(0.1069)\end{array}$ \\
\hline Control for Collateral (no) & $\begin{array}{c}-0.0297 \\
(0.0182)\end{array}$ & $\begin{array}{c}-0.0201 \\
(0.0172)\end{array}$ & $\begin{array}{c}-0.0226 * \\
(0.0134)\end{array}$ & $\begin{array}{c}-0.0237^{*} \\
(0.0127)\end{array}$ & $\begin{array}{c}-0.4147 * * * \\
(0.0719)\end{array}$ & $\begin{array}{c}-0.1902 * * \\
(0.0843)\end{array}$ \\
\hline Control for Inflation (no) & $\begin{array}{l}-0.0139 \\
(0.0225)\end{array}$ & $\begin{array}{l}-0.0021 \\
(0.0279)\end{array}$ & $\begin{array}{l}-0.0026 \\
(0.0175)\end{array}$ & $\begin{array}{l}-0.0013 \\
(0.0188)\end{array}$ & $\begin{array}{l}-0.0200 \\
(0.0318)\end{array}$ & $\begin{array}{c}-0.0299 \\
(0.0335)\end{array}$ \\
\hline Control for Industry Typical-Leverage (no) & $\begin{array}{c}-0.0348 * \\
(0.0180)\end{array}$ & $\begin{array}{c}-0.0024 \\
(0.0177)\end{array}$ & $\begin{array}{c}0.0030 \\
(0.0142)\end{array}$ & $\begin{array}{c}0.0121 \\
(0.0132)\end{array}$ & $\begin{array}{c}-0.0930 \\
(0.0703)\end{array}$ & $\begin{array}{c}0.1065 \\
(0.0735)\end{array}$ \\
\hline Control for Capital Market Conditions (no) & $\begin{array}{l}-0.0342 * \\
(0.0194)\end{array}$ & $\begin{array}{l}-0.0054 \\
(0.0206)\end{array}$ & $\begin{array}{l}-0.0348 * \\
(0.0185)\end{array}$ & $\begin{array}{l}-0.0083 \\
(0.0220)\end{array}$ & $\begin{array}{l}-0.0887^{*} \\
(0.0486)\end{array}$ & $\begin{array}{l}-0.0378 \\
(0.0422)\end{array}$ \\
\hline Control for Political Risk (no) & $\begin{array}{c}0.2128 * * * \\
(0.0345)\end{array}$ & $\begin{array}{c}0.1327 * * * \\
(0.0387)\end{array}$ & $\begin{array}{c}0.1434 * * * \\
(0.0278)\end{array}$ & $\begin{array}{c}0.1017 * * * \\
(0.0315)\end{array}$ & $\begin{array}{c}0.2887 * * * \\
(0.0624)\end{array}$ & $\begin{array}{c}0.1472 \\
(0.0932)\end{array}$ \\
\hline Control for Market Growth (no) & $\begin{array}{c}0.0461 \\
(0.0462)\end{array}$ & $\begin{array}{c}0.0614 \\
(0.0505)\end{array}$ & $\begin{array}{c}0.0079 \\
(0.0468)\end{array}$ & $\begin{array}{c}0.0077 \\
(0.0533)\end{array}$ & $\begin{array}{c}0.1567 * \\
(0.0802)\end{array}$ & $\begin{array}{c}0.2691 * * * \\
(0.0851)\end{array}$ \\
\hline \multicolumn{7}{|l|}{ Data Sample Characteristics } \\
\hline $\begin{array}{l}\text { Average Sample Year } \\
\text { Publication Selection }\end{array}$ & $\begin{array}{c}0.00255 \\
(0.00188)\end{array}$ & $\begin{array}{l}0.000843 \\
(0.00281)\end{array}$ & $\begin{array}{c}0.00484^{* * *} \\
(0.00186)\end{array}$ & $\begin{array}{l}0.00371^{*} \\
(0.00200)\end{array}$ & $\begin{array}{c}0.0499 * * * \\
(0.00921)\end{array}$ & $\begin{array}{c}0.0434 \\
(0.0293)\end{array}$ \\
\hline Primary Standard Error & $\begin{array}{c}1.8541^{* * *} \\
(0.2038)\end{array}$ & $\begin{array}{c}0.9491 * * * \\
(0.2450)\end{array}$ & $\begin{array}{c}1.8187 * * * \\
(0.1839)\end{array}$ & $\begin{array}{c}1.2863 * * * \\
(0.1951)\end{array}$ & & \\
\hline Database Dummies Included in Meta-Regression & No & Yes & No & Yes & No & Yes \\
\hline Number of Primary Estimations & 352 & 352 & 453 & 453 & 428 & 428 \\
\hline Adj. $R^{2}$ & 0.777 & 0.807 & 0.726 & 0.754 & 0.568 & 0.649 \\
\hline
\end{tabular}


Primary studies using cross-country data must control for the various differences in the economic and institutional environment possibly affecting capital structures of subsidiaries. We identify three main groups of extra control variables which are used in international studies. These capture the conditions of the host country capital market, political risk, and market growth. We code three additional dummy variables respectively indicating if these aspects are included in primary studies. However, the meta-regressions in columns (3) and (4) of Table V suggest that only the inclusion of political risk has a particular influence on identified tax effects in international capital structure regressions. This finding is very reasonable if political risk and host country tax levels are supposed to be negatively correlated. More risky host countries, e.g., in Eastern Europe, indeed tend to have lower tax rates in order to attract FDI. Furthermore, recent studies suggest that multinationals finance subsidiaries in high risk countries particularly heavily with debt (Desai et al. (2008); Kesternich and Schnitzer (2010)). Disregarding political risk in capital structure regressions should thus be associated with a downward bias of the identified tax effect. Consistently, the meta-coefficient for controlling for political risk in columns (3) and (4) is significant and positive. The effect of 0.143 , for example, in column (3) is also qualitatively important.

Regarding the magnitudes of the reported tax effects, let us, for example, consider specification (3) of Table V. If we consider a hypothetical study that considers total debt and simply employs the statutory tax rate but at the same time takes on all other characteristics that are statistically significant in column (3), a marginal tax effect of about 0.198 is predicted. If an average tax rate is considered, the predicted tax effect is even higher and amounts to 0.328 . 
The nature of the tax influence on capital structures of multinational subsidiaries however is complex. To be precise, primary estimates of the tax effect on debt policy differ in capturing either the incentives coming from the domestic tax system or, in addition, from the interplay of domestic and potentially numerous foreign tax regimes. In a purely domestic context, the marginal tax rate reflects the tax advantage of debt over equity financing. Its variation thus implies changes in the value of the corporate interest tax shield, prompting the firm to rebalance debt and equity finance. If multinational firms are involved, they might in addition adjust the intra-company allocation of internal funds in response to the shift in the relative tax attractiveness of a location. This international tax effect on a subsidiary's debt ratio then adds to the domestically motivated adjustment of corporate debt policy. ${ }^{24}$

By sample composition or by matter of econometric specification, a few primary studies empirically split up the overall tax effect on debt. In other words, they isolate what is called the international tax effect from the pure impact of the domestic tax system on debt ratios. To gain insights on the relative importance of both effects constituting the overall tax impact, we code a dummy variable Profit-Shifting Tax Effect which takes on the value of one if estimates refer to purely profit-shifting incentives and a value of zero if the total tax effect is reflected. We also consider an additional dummy Tax Effect Controlled for Profit-Shifting Effect that marks estimates reflecting the tax effect of the domestic tax system, i.e. the remaining tax effect if the profit-shifting effect is already controlled for. The two respective meta-regression coefficients in columns (3) and (4) of Table V show a negative sign but the effect for the profit-shifting activity is only statistically significant if database fixed effects are considered. The estimated effects are

\footnotetext{
${ }^{24}$ For a thorough discussion see Huizinga et al. (2008).
} 
also rather small. Consequently, each effect deviates only very slightly from the tax effect found in studies that less carefully model the complex tax incentives in multinationals. This means that the total tax effect almost doubles if a study carefully accounts for the international tax incentive, because a subsidiary is simultaneously confronted with both incentives from the host-country tax and from cross-border profit-shifting opportunities.

An example helps to clarify the complex nature of tax incentives associated with multinational activity. Let us, once again, consider column (3) and look at the aforementioned hypothetical study taking on all significant study characteristics except elaborate tax variables and intracompany debt. First, the results suggest that a rising host country tax rate exerts a marginal effect on debt-to asset ratios of about 0.164 . Secondly, due to cross-border profit shifting incentives, the tax-rate differential between the host-country tax level and the tax level at other locations of the multinational firm entails an additional marginal tax effect of about 0.198. Consequently, the debt ratio of a multinational subsidiary is affected by variation in both the host country tax level and the tax level at the other locations of the multinational group. If the host country tax rate rises by one percentage point, the regression results suggest an increase of the debt ratio by 0.362 because the internal reallocation of debt financing within the multinational group adds to the generally higher attractiveness of debt financing. Not surprisingly, this predicted marginal tax effect for the tax response of multinational subsidiaries is much higher than marginal tax effects predicted for estimates excluding multinational firms.

We can compare our results, for example, with predicted effects using regression results found for the sample that excludes studies focusing exclusively on multinational subsidiaries (see 
subsection C). The marginal tax effect predicted for a corresponding specification is $0.201 .^{25}$ This effect size is surprisingly close to what can be expected to be found in multinational firm data analyses (0.198) if they do not adequately account for the complex tax incentives at work in a multinational. Thus, our findings support the view that the complex nature of the tax incentives associated with multinational activities needs a very careful consideration in an empirical analysis of capital structures. Taking our numerical examples seriously, a study that does not disentangle the different tax incentives of multinational subsidiaries tends to significantly underreport the tax response of capital structures.

The international tax system entails an additional impact on financial policy within multinational firms. Generally, two different systems of double taxation avoidance are applied. One group of countries simply exempts foreign dividends (exemption system). In this case, a multinational firm immediately benefits from reductions in foreign tax payments due to tax optimal debt financing. By contrast, in some countries, e.g. the US, foreign source income is taxed but foreign tax payments can be deducted from domestic tax liabilities (credit system). Under the credit system, benefits from tax avoidance abroad are offset by tax payments at the parent-company level when profits are repatriated. Therefore, we construct a dummy variable Credit System to identify estimates which rely on data of parent firms resident in home countries that apply the credit system. Our regression results, however, do not confirm that tax effects differ across different systems of international taxation.

\footnotetext{
${ }^{25}$ We refer to column (1) of Table IV and consider a case where the statutory tax rate, a static econometric specification and all other characteristics that prove to be statistically significant are chosen.
} 
If a primary study only refers to intra-company debt, the results of column (3) suggest that the marginal tax effect is reduced by 0.078 . However, there are good reasons to expect that intracompany debt reacts more intensively to tax rate changes. Desai et al. (2004) point out that tapping internal capital markets might come along with significant cost advantages as compared to external funding if local capital market conditions are weak. Furthermore, for multinational firms the fine-tuning of internal finances can serve as an important tax planning tool, used to minimize companywide tax payments. Yet, Desai et al. (2004) carefully hint at external debt generally taking up a larger share in total debt than intra-company borrowing. The metaregressions in columns (1) to (4) suggest that the arguments discussed above have not translated into larger marginal tax effects on intra-company debt ratios. However, marginal tax effects are not normalized with respect to initial debt shares and potentially hidden build-up costs. By contrast, the semi-elasticity is an instructive indicator if the interest does not lie in the absolute response of debt ratios but in relative response intensities.

Therefore, we consistently transform the marginal tax effect found in primary studies into a semi-elasticity of the debt ratio. The latter reflects the percentage change in the debt ratio in response to a one percentage-point change in the tax rate. As almost all primary estimates sampled from the literature represent marginal tax effects, we can only evaluate the semielasticities at the respective sample means of the debt ratio. Equation (3) illustrates the semielasticity (se) more formally, where $d$ represents the corporate debt ratio and $\tau$ is the tax rate:

$$
\text { se }=\frac{\partial \mathrm{d}}{\mathrm{d}} \cdot \frac{1}{\partial \tau}
$$


In columns (5) and (6) of Table $\mathrm{V}$ the dependent variable of the meta-regressions now is the tax semi-elasticity as defined in equation (3). ${ }^{26}$ The regression results suggest that the relative response of intra-company debt to taxes is indeed significantly more intense as compared to other debt items.

With regard to the magnitudes of the estimated effects, let us consider column (5) of Table V. If we begin once again by assuming the aforementioned hypothetical study that produces a marginal effect of 0.164 , the semi-elasticity of the debt ratio to a rising host country tax rate is predicted to be 0.313 . The corresponding semi-elasticity for a fall in the tax level at other locations of the multinational group is 0.146 . If however only intra-company debt is considered, predicted semi-elasticities are significantly higher and amount to 0.470 or 0.302 , respectively. Generally, on the basis of all primary evidence, intra-company debt is confirmed to be a flexibly used tax planning device.

\section{Conclusions}

The empirical evidence with regard to the tax impact on corporate debt policy is strongly varied. This gives reason to provide a first quantitative survey of the literature. Taking recourse to metaregression analysis, we offered explanations for why reported tax effects appear heterogeneous. After we have synthesized the evidence from 1,143 point estimates of marginal tax effect on the corporate debt ratio sampled out of 46 primary analyses, we conclude that capital structure choices are indeed positively affected through taxes. The effect is also quantitatively important.

\footnotetext{
${ }^{26}$ In columns (5) and (6) of Table $\mathrm{V}$, the number of observations falls slightly because information provided in the study by Jog and Tang (2001) does not allow to calculate semi-elasticities of debt ratios.
} 
Our findings suggest that very small or even negative tax estimates found in a couple of studies do not reflect the true debt response to taxes. By contrast, accounting for all potential misspecification biases, we predict a marginal tax effect on the debt ratio of 0.30 , based on results in column (6) of Table II. Hence, the debt-to-assets ratio rises by 3 percentage points if the simulated marginal tax rate increases by 10 percentage points.

A comparison with other capital structure determinants puts the magnitude of the predicted tax effect into perspective. Let us, for example, consider tangibility which is usually defined as the ratio of tangible assets to total assets. According to a recent study by Frank and Goyal (2007) the marginal response of capital structures to tangibility oscillates around 0.126 . Accordingly, the debt response to tangibility is only one-third of the response to taxes. The empirical results of our meta-study thus support the view that taxes are quite an important determinant of capital structure choices.

Furthermore, our meta-regression results show that the point estimates of tax effects are, in particular, affected by the tax rate proxy used for identification. We find very robust evidence that, as compared to statutory tax rates, simulated marginal tax rates are associated with significantly higher estimates for the tax coefficient. Average tax rates instead may introduce a significant downward bias in primary estimates which is due to endogeneity. In general, we can conclude that a careful consideration of the firm-specific tax status raises the magnitude of identified tax effects on corporate debt policy.

Moreover, the results of the meta-analysis suggest that the set of explanatory variables considered in a primary study significantly affect reported tax effects. Disregarding one type of 
control variable is indeed quantitatively important. In addition, the long-term response of capital structures to taxes identified in dynamic models exceeds in magnitude the response estimated in static models. Interestingly, we find that unobserved firm effects do not affect isolated tax effects on debt policy.

In additional regressions, we focused on tax effect estimates with regard to multinational debt financing. We document that, due to the complex nature of tax incentives associated with multinational activity, an empirical analysis must carefully model the additional effect arising from cross-border profit shifting opportunities. Moreover, our results suggest that the relative tax sensitivity of intercompany debt financing is particularly strong. Interestingly, our meta-analysis does not corroborate the view that the international tax system affects the tax effect on debt financing of multinational firms.

Finally, the results of our meta-analysis may guide further empirical research: For the fast growing literature on multinationals' debt financing, it might be an interesting challenge to consider the firm's tax status more carefully, e.g., by using simulated marginal tax rates. Since previous dynamic estimations have predominantly referred to potentially endogenous average tax rates, another challenge could be to estimate a dynamic model with a better proxy for the marginal tax incentive. Generally, future research can benefit from the insights on how various study characteristics quantitatively affect estimated tax effects. 


\section{APPENDIX}

\section{Table VI}

\section{Papers on Tax Response of Corporate Capital Structure Included in the Meta-Analysis}

Sample A denotes the basic sample containing all marginal tax effects on the debt ratio which mainly result from variation in the domestic tax rate. In some cases these effects might jointly reflect both domestic tax incentives and the international profit shifting incentive. Sample B excludes estimates based on pure multinational firm data. By contrast, Sample C contains only tax effect estimates drawn from studies which focus exclusively on multinational subsidiaries.

\begin{tabular}{|c|c|c|c|c|c|c|c|c|}
\hline & \multirow{2}{*}{ Study } & \multirow{2}{*}{ Sample } & \multirow{2}{*}{$\begin{array}{c}\text { No. } \\
\text { of effects }\end{array}$} & \multicolumn{5}{|c|}{ Marginal tax effects on debt } \\
\hline & & & & Mean & Median & Min & Max & Std. \\
\hline 1 & Aggarwal \& Kyaw, 2008 & $\mathrm{C}$ & 12 & 0.24 & 0.23 & 0.03 & 0.44 & 0.12 \\
\hline 2 & Altshuler \& Grubert, 2003 & $\mathrm{~A}, \mathrm{C}$ & 6 & 0.17 & 0.13 & -0.02 & 0.39 & 0.16 \\
\hline 3 & Antoniou et al., 2008 & A, C & 23 & 0.00 & 0.00 & -0.05 & 0.04 & 0.02 \\
\hline 4 & Barion et al., 2010 & A, B & 4 & 0.39 & 0.37 & 0.29 & 0.52 & 0.10 \\
\hline 5 & Bartholdy \& Mateus, 2008 & A, B & 81 & 0.05 & 0.00 & -2.30 & 2.59 & 0.44 \\
\hline 6 & Bauer, 2004 & A, C & 8 & 0.07 & 0.05 & -0.05 & 0.24 & 0.12 \\
\hline 7 & Booth et al., 2001 & A, B & 78 & -0.03 & -0.03 & -0.47 & 0.3 & 0.13 \\
\hline 8 & Buettner et al., 2008 & A, C & 9 & 0.10 & 0.16 & -0.10 & 0.20 & 0.12 \\
\hline 9 & Buettner et al., 2009 & A, C & 6 & 0.18 & 0.18 & 0.14 & 0.24 & 0.04 \\
\hline \multirow[t]{2}{*}{10} & Buettner \& Wamser, 2009 & A & 73 & 0.05 & 0.03 & -0.07 & 0.14 & 0.06 \\
\hline & & $\mathrm{C}$ & 115 & 0.06 & 0.08 & -0.07 & 0.14 & 0.05 \\
\hline 11 & Byoun, 2008 & A, B & 8 & -0.05 & -0.05 & -0.11 & 0.00 & 0.04 \\
\hline 12 & Charalambakis et al., 2008 & A, B & 10 & 0.04 & 0.05 & 0.01 & 0.06 & 0.02 \\
\hline 13 & Chen \& Strange, 2005 & A, B & 4 & 0.00 & 0.00 & -0.02 & 0.03 & 0.02 \\
\hline 14 & Cheng \& Green, 2008 & A, B & 6 & 0.01 & 0.01 & 0.00 & 0.01 & 0.01 \\
\hline 15 & De Jong et al., 2008 & A & 42 & -0.06 & 0.00 & -1.10 & 0.10 & 0.19 \\
\hline 16 & Desai, Foley \& Hines, 2004 & A, C & 32 & 0.18 & 0.17 & 0.05 & 0.40 & 0.09 \\
\hline \multirow[t]{2}{*}{17} & Dischinger et al., 2010 & A & 50 & 0.31 & 0.30 & 0.09 & 0.67 & 0.14 \\
\hline & & $\mathrm{C}$ & 72 & 0.23 & 0.24 & 0.02 & 0.67 & 0.16 \\
\hline 18 & Dwenger \& Steiner, 2009 & A, B & 13 & 1.88 & 2.14 & -0.84 & 3.82 & 1.45 \\
\hline 19 & Faulkender \& Petersen, 2006 & A, B & 1 & -0.14 & -0.14 & -0.14 & -0.14 & . \\
\hline 20 & Gordon \& Lee, 2001 & A, B & 9 & -0.02 & 0.05 & -0.42 & 0.30 & 0.23 \\
\hline 21 & Gordon \& Lee, 2007 & A, B & 29 & 0.10 & 0.11 & -0.07 & 0.30 & 0.08 \\
\hline 22 & Graham, 1999 & A, B & 97 & 0.11 & 0.12 & -0.04 & 0.25 & 0.06 \\
\hline 23 & Graham et al., 1998 & A, B & 2 & -0.03 & -0.03 & -0.13 & 0.07 & 0.15 \\
\hline 24 & Graham et al., 2004 & A, B & 15 & 0.17 & 0.18 & 0.06 & 0.31 & 0.06 \\
\hline
\end{tabular}


Table VI

(Continued)

\begin{tabular}{|c|c|c|c|c|c|c|c|c|}
\hline & \multirow{2}{*}{ Study } & \multirow{2}{*}{ Sample } & \multirow{2}{*}{$\begin{array}{c}\text { No. } \\
\text { of effects }\end{array}$} & \multicolumn{5}{|c|}{ Marginal tax effects on debt } \\
\hline & & & & Mean & Median & Min & $\operatorname{Max}$ & Std. \\
\hline 25 & Green \& Murinde, 2008 & A, B & 8 & -0.01 & 0.01 & -0.22 & 0.05 & 0.09 \\
\hline 26 & Hebous \& Weichenrieder, 2010 & A, C & 28 & 0.11 & 0.09 & -0.95 & 2.05 & 0.61 \\
\hline 27 & Homaifar et al., 1994 & A, B & 14 & 0.36 & -0.05 & -2.13 & 3.32 & 1.93 \\
\hline 28 & Huang \& Ritter, 2009 & A, B & 24 & -0.24 & -0.29 & -0.95 & 0.69 & 0.34 \\
\hline \multirow[t]{3}{*}{29} & Huizinga et al., 2008 & A & 58 & 0.23 & 0.21 & 0.11 & 0.34 & 0.05 \\
\hline & & $\mathrm{B}$ & 54 & 0.22 & 0.21 & 0.11 & 0.32 & 0.05 \\
\hline & & $\mathrm{C}$ & 6 & 0.21 & 0.22 & 0.09 & 0.34 & 0.10 \\
\hline \multirow[t]{3}{*}{30} & Jog \& Tang, 2001 & A & 13 & 0.42 & 0.41 & -0.08 & 0.89 & 0.28 \\
\hline & & $\mathrm{B}$ & 3 & 0.49 & 0.52 & 0.41 & 0.53 & 0.07 \\
\hline & & $\mathrm{C}$ & 12 & 0.38 & 0.38 & -0.08 & 0.89 & 0.30 \\
\hline 31 & Kesternich \& Schnitzer, 2010 & A, C & 7 & 0.20 & 0.20 & 0.18 & 0.22 & 0.01 \\
\hline 32 & Klapper \& Tzioumis, 2008 & A, B & 10 & 0.06 & 0.05 & 0.03 & 0.19 & 0.05 \\
\hline 33 & Lasfer, 1995 & A, B & 6 & 0.00 & 0.00 & -0.01 & 0.01 & 0.00 \\
\hline 34 & Liu \& Tian, 2009 & A, B & 12 & 0.02 & 0.01 & -0.02 & 0.08 & 0.03 \\
\hline 35 & López-Gracia \& Sorgorb-Mira, 2008 & A, B & 6 & 0.00 & 0.00 & 0.00 & 0.00 & 0.00 \\
\hline 36 & Michaelas et al., 1999 & A & 3 & -0.04 & -0.03 & -0.05 & -0.03 & 0.02 \\
\hline 37 & Moore \& Ruane, 2005 & A, C & 43 & 0.32 & 0.34 & -0.02 & 0.83 & 0.13 \\
\hline 38 & Mills \& Newberry, 2004 & $\mathrm{C}$ & 2 & 0.31 & 0.31 & 0.12 & 0.49 & 0.26 \\
\hline 39 & Mintz \& Weichenrieder, 2010 & A, C & 42 & 0.10 & 0.08 & -0.13 & 0.44 & 0.12 \\
\hline 40 & Oeztekin, 2009 & A, B & 76 & 0.00 & 0.00 & -0.19 & 0.34 & 0.06 \\
\hline 41 & Overesch \& Voeller, 2010 & A, B & 22 & 0.14 & 0.12 & -0.29 & 0.44 & 0.19 \\
\hline 42 & Overesch \& Wamser, 2010 & $\mathrm{C}$ & 15 & 0.34 & 0.21 & 0.19 & 0.78 & 0.23 \\
\hline 43 & Pfaffermayr et al., 2008 & A, B & 20 & 0.61 & 0.71 & 0.19 & 1.02 & 0.24 \\
\hline 44 & Ruf 2010 & A, C & 3 & 0.45 & 0.45 & 0.45 & 0.47 & 0.01 \\
\hline \multirow[t]{2}{*}{45} & Ramb \& Weichenrieder, 2005 & A & 8 & 0.03 & 0.03 & -0.02 & 0.14 & 0.05 \\
\hline & & $\mathrm{C}$ & 12 & 0.02 & 0.02 & -0.04 & 0.14 & 0.05 \\
\hline \multirow[t]{5}{*}{46} & Shivdasani et al., 2010 & A, B & 3 & 0.04 & 0.05 & 0.01 & 0.06 & 0.03 \\
\hline & Basic Sample (A) & & 1012 & 0.13 & 0.07 & -2.30 & 3.82 & 0.42 \\
\hline & Excluding Pure Multinational Stud & & 660 & 0.11 & $\mathbf{0 . 0 3}$ & -2.30 & 3.82 & 0.48 \\
\hline & Exclusively Multinational Studies ( & & 453 & 0.16 & 0.11 & -0.95 & 1.05 & 0.22 \\
\hline & Overall Meta-Dataset & & 1143 & 0.13 & 0.08 & -2.30 & 3.82 & 0.39 \\
\hline
\end{tabular}




\section{REFERENCES}

Aggarwal, R., and N.A. Kyaw, 2008, Internal Capital Networks as a Source of MNC Competitive Advantage: Evidence from Foreign Subsidiary Capital Structure Decisions, Research in International Business and Finance 22, 409-439.

Altshuler, R., and H. Grubert, 2003, Repatriation Taxes, Repatriation Strategies and Multinational Financial Policy, Journal of Public Economics 87, 73-107.

Alworth, J., and G. Arachi, 2001, The Effect of Taxes on Corporate Financing Decisions: Evidence from a Panel of Italian Firms, International Tax and Public Finance 8, 353-376.

Amromin, G., and N. Liang, 2003, Hedging Employee Stock Options, Corporate Taxes and Debt, National Tax Journal 56, 513-533.

Antoniou, A., Y. Guney, and K. Paudya, 2008, The Determinants of Capital Structure: Capital Market-Oriented versus Bank-Oriented Institutions, Journal of Financial and Quantitative Analysis 43, 59-92.

Ayers, B.C., C.B. Cloyd, and J.R. Robinson, 2001, The Influence of Income Taxes on the Use of Inside and Outside Debt by Small Businesses, National Tax Journal 54, 27-55.

Barclay, M.J., and C.W. Smith Jr., 1995, The Priority Structure of Corporate Liabilities, Journal of Finance 50, 899-917.

Baker, M., and J. Wurgler, 2002, Market Timing and Capital Structure, Journal of Finance 57, 132.

Barion, F., R. Miniaci, P.M. Panteghini, and M.L. Parisi, 2010, Profit Shifting via Debt Financing in Europe, Working Paper, Università di Brescia.

Bartholdy, J., and C. Mateus, 2008, Taxes and Corporate Debt Policy: Evidence for Unlisted Firms of Sixteen European Countries, Working Paper, University of Arhus.

Bauer, P., 2004, Determinants of Capital Structure - Empirical Evidence from the Czech Republic, Czech Journal of Economics and Finance 54, 2-21.

Blouin, J., J.E. Core, and W. Guay, 2010, Have the Tax Benefits of Debt Been Overestimated? Journal of Financial Economics 98, 195-213.

Booth, L., V. Aivazian, A. Demirguc-Kunt, and V. Maksimovic, 2001, Capital Structures in Developing Countries, Journal of Finance 56, 87-130.

Buettner, T., M. Overesch, U. Schreiber, and G. Wamser, 2008, The Impact of ThinCapitalization Rules on Multinationals' Financing and Investment Decisions, Bundesbank Discussion Paper 03/2008, Frankfurt.

Buettner, T., M. Overesch, U. Schreiber, and G. Wamser, 2009, Taxation and Capital Structure Choice - Evidence from a Panel of German Multinationals, Economics Letters 105, 309-311. 
Buettner, T., and G. Wamser, 2009, Internal Debt and Multinationals' Profit Shifting - Empirical Evidence from Firm-Level Panel Data, Working Paper, Oxford University Centre for Business Taxation.

Byoun, S., 2008, How and When Do Firms Adjust Their Capital Structures toward Targets?, Journal of Finance 63, 3069-3096.

Card, D. and A.B. Krueger, 1995, Time-Series Minimum-Wage Studies: A Meta-Analysis, American Economic Review (Papers and Proceedings) 85, pp. 238-43

Card, D., J. Kluve, and A. Weber, 2010, Active Labor Market Policy Evaluations: A Metaanalysis, Economic Journal, forthcoming.

Charalambakis, E.C., S.K. Espenlaub, and I. Garrett, 2008, Leverage Dynamics, the Endogeneity of Corporate Tax Status and Financial Distress Costs, and Capital Structure, Working Paper, Manchester Business School.

Chen, J., and R. Strange, 2005, The Determinants of Capital Structure: Evidence from Chinese Listed Companies, Economic Change and Restructring 38, 11-35.

Cheng, Y., and C.J. Green, 2008, Taxes and Capital Structure: A Study of European Companies, Manchester School, Supplement 2008, 85-115.

DeAngelo, H., and R.W. Masulis, 1980, Optimal Capital Structure under Corporate and Personal Taxation, Journal of Financial Economics 8, 3-29.

De Jong, A., R. Kabir, and T.T. Nguyen, 2008, Capital Structure Around the World: The Roles of Firm- and Country-Specific Determinants, Journal of Banking and Finance 32, 1954-1969.

De Long, J.B., and K. Lang, 1992, Are All Economic Hypotheses False?, Journal of Political Economy 100, 1257-72.

De Mooij, R.A., and S. Ederveen, 2003, Taxation and Foreign Direct Investment: A Synthesis of Empirical Research, International Tax and Public Finance 10, 673-693.

Desai, M.A., C.F. Foley, and J.R. Hines, 2004, A Multinational Perspective on Capital Structure Choice and Internal Capital Markets, Journal of Finance 59, 2451-2487.

Desai, M.A., C.F. Foley, and J.R. Hines, 2008, Capital Structure with Risky Foreign Investment, Journal of Financial Economics 88, 534-553.

Dhaliwal, D., R. Trezevant, and S. Wang, 1992, Taxes, Investment Related Tax Shields and Capital Structure. Journal of the American Taxation Association 14, 1-21.

Dischinger, M., U. Glogowski, and M. Strobel, 2010, Leverage, Corporate Taxes and Debt Shifting of Multinationals: The Impact of Firm-Specific Risk, Working Paper, University of Munich.

Downs, T.W., 1993, Corporate Leverage and Non-Debt Tax Shields: Evidence on Crowding-Out, Financial Review 28, 549-583.

Dwenger, N., and V. Steiner, 2009, Financial Leverage and Corporate Taxation. Evidence from German Corporate Tax Return Data, Working Paper, German Institute for Economic Research. 
Egger, M., G.D. Smith, M. Scheider, and C. Minder, 1997, Bias in Meta-Analysis Detected by a Simple, Graphical Test, British Medical Journal 316, 629-634.

Fama, E.F., and K.R. French, 2002, Testing Trade-Off and Pecking Order Predictions about Dividends and Debt, Review of Financial Studies 15, 1-33.

Faulkender, M., and M.A. Petersen, 2006, Does the Source of Capital Affect Capital Structure? Review of Financial Studies 19, 45-79.

Flannery, M.J., and K.P. Rangan, 2006, Partial Adjustment toward Target Capital Structures, Journal of Financial Economics 79, 469-506.

Feld, Lars P., and Jost H. Heckemeyer 2011, FDI and Taxation: A Meta-Study, Journal of Economic Surveys 25, 233-275.

Frank, M.Z., and V.K. Goyal, 2007, Capital Structure Decisions: Which Factors Are Reliably Important? Financial Management 38, 1-37.

Goerg, H., and E. Strobl, 2001, Multinational Companies and Productivity Spillovers: A MetaAnalysis, Economic Journal 111, 723-740.

Gordon, R.H., 2010, Taxation and Corporate Use of Debt: Implications for Tax Policy, National Tax Journal 63, 151-174.

Gordon, R.H., and Y. Lee, 2001, Do taxes affect corporate debt policy? Evidence from U.S. Corporate Tax Return Data, Journal of Public Economics 82, 195-224.

Gordon, R.H., and Y. Lee, 2007, Interest Rates, Taxes and Corporate Financial Policies, National Tax Journal 60, 65-84.

Graham, J.R., 1996a, Debt and the Marginal Tax Rate, Journal of Financial Economics 41, 4173.

Graham, J.R., 1996b, Proxies for the Corporate Marginal Tax Rate, Journal of Financial Economics 41, 187-221.

Graham, J.R., 1999, Do Personal Taxes Affect Corporate Financing Decisions? Journal of Public Economics 73, 147-185.

Graham, J.R., 2003, Taxes and Corporate Finance: A Review, Review of Financial Studies 16, 1075-1129.

Graham, J., and H. Kim 2009, The Effects of the Length of the Tax-Loss Carryback Period on Tax Receipts and Corporate Marginal Tax Rates, Working Paper, Duke University.

Graham, J.R., and L.F. Mills, 2008, Using Tax Return Data to Simulate Corporate Marginal Tax Rates, Journal of Accounting and Economics 46, 366-388.

Graham, J.R., M.L. Lemmon, and J.S. Schallheim, 1998, Debt, Leases, Taxes, and the Endogeneity of Corporate Tax Status, Journal of Finance 53, 131-162.

Graham, J.R., M.H. Lang, and D.A. Shackelford, 2004, Employee Stock Options, Corporate Taxes, and Debt Policy, Journal of Finance 59, 1585-1617. 
Graham, J.R., and A.L. Tucker, 2006, Tax Shelters and Corporate Debt Policy, Journal of Financial Economics 81, S. 563-594.

Green, C.J., and V. Murinde, 2008, The Impact of Tax Policy on Corporate Debt in a Developing Economy: A Study of Unquoted Indian Companies, European Journal of Finance 14, 583607.

Greene, W.H., 2003, Econometric Analysis (Prentice Hall, Upper Saddle River, NJ.).

Hebous S., and A. Weichenrieder, 2010, Debt Financing and Sharp Currency Depreciations: Wholly versus Partially-Owned Multinational Affiliates, Review of World Economics 146, 281-306.

Hedges, L.V., and I. Olkin, 1985, Statistical Methods for Meta-Analysis (Academic Press, Orlando, FL.).

Homaifar, G., J. Zietz, and O. Benkato, 1994, An Empirical Model of Capital Structure: Some New Evidence, Journal of Business Finance and Accounting 21, 1-14.

Huang, R., and J.R. Ritter, 2009, Testing Theories of Capital Structure and Estimating the Speed of Adjustment, Journal of Financial and Quantitative Analysis 44, 237-271.

Huizinga, H., L. Laeven, and G. Nicodème, 2008, Capital Structure and International Debt Shifting in Europe, Journal of Financial Economics 88, 80-118.

Jensen, M., 1986, Agency Costs of Free Cash Flow, Corporate Finance and Takeovers, American Economic Review 76, 323-329.

Jensen, M., and W.H. Meckling, 1976, Theory of the Firm: Managerial Behavior, Agency Costs and Ownership Structure, Journal of Financial Economics 42, 159-185.

Jog, V., and J. Tang, 2001, Tax Reforms, Debt Shifting and Tax Revenues: Multinational Corporations in Canada, International Tax and Public Finance 8, 5-26.

Kesternich, I., and M. Schnitzer, 2010, Who is Afraid of Political Risk? Multinational Firms and their Choice of Capital Structure, Journal of International Economics, forthcoming.

Klapper, L., and K. Tzioumis, 2008, Taxation and Capital Structure - Evidence from a Transition Economy, Policy Research Paper No. 4753, World Bank.

Kraus, A., and R.H. Litzenberger, 1973, A State-Preference Model of Optimal Financial Leverage, Journal of Finance 28, 911-922.

Lasfer, A. M., 1995, Agency Costs, Taxes and Debt: The UK Evidence, European Financial Management 1, 265-285.

Lemmon, M.L., M.R. Roberts, and J.F. Zender, 2008, Back to the Beginning: Persistence and the Cross-Section of Corporate Capital Structure, Journal of Finance 63, 1575-1608.

Liu, Q., and G. Tian, 2009, Leverage Ratio and Determinants of Capital Structure in SMEs: Evidence from China, Working Paper, University of Wollongong.

López-Gracia, J., and F. Sogorb-Mira, 2008, Testing Trade-Off and Pecking Order Theories Financing SMEs, Small Business Economics 31, 117-136. 
MacKie-Mason, J., 1990, Do Taxes Affect Corporate Financing Decisions? Journal of Finance 45, 1471-1493.

Michaelas, N., F. Chittenden, and P. Poutziouris, 1999, Financial Policy and Capital Structure Choice in U.K. SMEs: Empirical Evidence from Company Panel Data, Small Business Economics 12, 113-130.

Miller, M., 1977, Debt and Taxes, Journal of Finance 32, 261-276.

Mills, L.F., and K.J. Newberry, 2004, Do Foreign Multinational's Tax Incentives Influence their U.S Income Reporting and Debt Policy?, National Tax Journal 57, 89-107.

Mintz, J., and A. Weichenrieder, 2010, The Indirect Side of Direct Investment - Multi-national Company Finance and Taxation (MIT Press, Cambridge).

Modigliani, F., and M. Miller, 1963, Corporate Income Taxes and the Cost of Capital: A Correction, American Economic Review 53, 433-443.

Moore, P.J., and F.P. Ruane, 2005, Taxation and the Financial Structure of Foreign Direct Investment, Discussion Paper 88, Institute for International Integration Studies.

Myers, S., 1977, Determinants of Corporate Borrowing, Journal of Financial Economics 5, 147175.

Myers, S., 1984, The Capital Structure Puzzle, Journal of Finance 15, 81-102.

Myers, S., und N. Majluf, 1984, Corporate Financing and Investment Decisions when Firms Have Information that Investors Do not Have, Journal of Financial Economics 13, 187-222.

Newberry, K.J., and D.S. Dhaliwal, 2001, Cross-Jurisdictional Income Shifting by US Multinationals: Evidence from International Bond Offerings, Journal of Accounting Research 39, 643-662.

Oeztekin, Ö., 2009, Capital Structure Decisions Around the World: Which Factors are Reliably Important?, Working Paper, University of Kansas.

Overesch, M., and D. Voeller, 2010, The Impact of Personal and Corporate Taxation on Capital Structure Choices, FinanzArchiv 66, 263-294.

Overesch, M., and G. Wamser, 2010, Corporate Tax Planning and Thin-Capitalization Rules: Evidence from a Quasi Experiment, Applied Economics 42, 563-573.

Parrino, R., and M.S. Weisbach, 1999, Measuring Investment Distortions Arising from Stockholder-Bondholder Conflicts, Journal of Financial Economics 53, 3-42.

Pfaffermayr, M., M. Stoeckl, and H. Winner, 2008, Capital Structure, Corporate Taxation and Firm Age, Working Paper, Oxford University Centre for Business Taxation.

Rajan, R.G., and L. Zingales, 1995, What Do We Know about Capital Structure? Some Evidence from International Data, Journal of Finance 50, 1421-1460.

Ramb, F., and A. Weichenrieder, 2005, Taxes and the Financial Structure of German inward FDI, Review of World Economics 141, 670-692. 
Ruf, M., 2010, Trade Off or Pecking Order - What Drives the Leverage of Subsidiaries in High Tax Countries up?, Working Paper, University of Mannheim.

Scholes, M.S., and M.A. Wolfson, 1992. Taxes and Business Strategy - A Planning Approach (Prentice-Hall, Englewood Cliffs, NJ.).

Sharpe, S.A., and H.H. Nguyen, 1995, Capital Market Imperfections and the Incentive to Lease, Journal of Financial Economics 39, 271-294.

Shevlin, T., 1990, Estimating Corporate Marginal Tax Rates with Asymmetric Tax Treatment of Gains and Losses, Journal of the American Taxation Association 12, 51-67.

Shivdasani, A., and I. Stefanescu, 2010, How Do Pensions Affect Corporate Capital Structure Decisions?, Review of Financial Studies 23, 1287-1323.

Smith, V.K., and J.C. Huang, 1995, Can Markets Value Air Quality? A Meta-Analysis of Hedonic Property Value Models, Journal of Political Economy 103, 209-227.

Stanley, T.D., 2001, Wheat from Chaff: Meta-Analysis as Quantitative Literature Review, Journal of Economic Perspectives 15, 131-150.

Stanley, T.D., 2008, Meta-Regression Methods for Detecting and Estimating Empirical Effects in the Presence of Publication Selection, Oxford Bulletin of Economics and Statistics 70, 103127.

Stanley, T.D., and S.B. Jarrell, 1998, Gender Wage Discrimination Bias? A Meta-Regression Analysis, Journal of Human Resources 33, 947-73.

Stulz, R., 1990, Managerial Discretion and Optimal Financing Choices, Journal of Financial Economics 26, 3-28.

Titman, S., and R. Wessels, 1988, The Determinants of Capital Structure Choice, Journal of Finance 43, 1-19.

Trezevant, R., 1992, Debt Financing and Tax Status: Tests of the Substitution Effect and the Tax Exhaustion Hypothesis Using Firms' Response to the Economic Recovery Tax Act of 1981, Journal of Finance 47, 1557-1568. 